\title{
THE CUSTOMARY INTERNATIONAL LAW DOC- TRINE OF HUMANITARIAN INTERVENTION: ITS CURRENT VALIDITY UNDER THE U.N. CHARTER
}

\section{JEAN-PIERRE L. FONTEYNE*}

The Indian action in the 1971 Bangladesh crisis $^{1}$ has recently revived the debate among scholars on the question of the legality of unilateral ${ }^{2}$ humanitarian $^{3}$ intervention $^{4}$ under the U.N. Charter.

* Lecturer in Law, University of the West Indies, Faculty of Law. J.D., State University of Ghent; LL.M., University of Virginia, School of Law.

The assistance of Professor Richard B. Lillich is gratefully acknowledged.

All textual translations were provided by the author.

1. See generally INT'L COMM'N OF JuRISTS, The EVENTS IN EAST PakTSTAN, 1971 (1972) [hereinafter cited as INT'L COMM'N OF JURISTS]; Nanda, $A$ Critique of the United Nations Inaction in the Bangladesh Crisis, 49 DenVER L. J. 53 (1972) [hereinafter cited as Nanda, Critique]; Nanda, Self-Determination in International Law: The Tragic Tale of Two Cities-Islamabad (West Pakistan) and Dacca (East Pakistan) 66 AM. J. INT'L L. 321 (1972) [hereinafter cited as Nanda, Self-Determination]; Documents: Civil War in Pakistan, 4 N. Y. U. J. INT'L \& POL. 524 (1971).

2. Throughout this article the term unilateral intervention will be used as a generic term to denote intervention either by a single State (individual intervention) or by a group of States (collective intervention). Recent examples of the former are provided by the 1956 Soviet intervention in Hungary, the 1958 U.S. intervention in Lebanon, the 1969 British "mini-intervention" in Anguilla, and the Indian intervention in East Pakistan. The latter can be illustrated by the joint French-British-Israeli intervention in the $1956 \mathrm{Suez}$ crisis, the SEATO intervention in South Vietnam, the 1964 Stanleyville airdrop carried out in cooperation by Beigium, the United States, and the United Kingdom, the intervention by the Members of the Warsaw Pact in Czechoslovakia (1968), and the joint U S.-South Vietnamese intervention in Cambodia (1970). Unilateral intervention is essentially characterized by the lack of formal authorization from any competent international body, universal or regional, and in the case of collective unilateral intervention, by the non-institutionalized character of the association of States carrying out the intervention. Unilateral intervention must be distinguished on the one hand from intervention by armed forces under the direct control of the United Nations (Korea, UNEF, ONUC, Cyprus) or of an appropriate regional organization (1965 intervention in the Dominican Republic, in its second stage, after the "take-over" by the Organization of American States), and on the other hand from individual or collective intervention duly authorized by such an organization (first stage of the intervention in the Dominican Republic, carried out by the United States, but subsequently "ratified" by the Organization of American States).

3. Humanitarian intervention has been defined as: 
With the exception of some vague and controversial allegations of self-defense by Indian spokesmen, ${ }^{5}$ India itself has not tried to justify its intervention in East Pakistan on international legal grounds. Specifically, she has not appealed to the doctrine of humanitarian intervention. ${ }^{6}$ Nevertheless, the failure of the Indian government to refer openly to this theory does not alter the fact that its course of action in the Bangladesh situation probably constitutes the clearest case of forceful individual humanitarian intervention in this century. The question which the Indian

[T] tants of another State from treatment so arbitrary and persistently abusive as to exceed the limits within which the sovereign is presumed to act with reason and justice.

E. Stowell, International Law 348 (1931). Compare Rougier, La Théorie de l'Intervention d'Humanité, 17 Revue Generale de Droit International PubLuQUe (Rev. Gen. Dr. INT'L PuBl.) 468, 472 (1910) [hereinafter cited as Rougier].

4. For the purposes of this article, the term intervention is defined as "dictatorial interference by a State [or group of States] in the affairs of another State for the purpose of maintaining or altering the actual conditions of things." 1 L. OPPENHEIM, INTERNATIONAL LAW 305 (8th ed. H. Lauterpacht 1955) thereinafter cited as OPPENHEIM]. This emphasizes that "intervention proper is always dictatorial interference, not interference pure and simple." Id. This definition rejects as too broad Accioly's definition: "Intervenção pode ser definida com a ingerência de um Estado nos negócios internos ou externos de outro Estado não dependents dêle, com a intenção de lhe impor certa maneira de proceder." H Accioly, Manual de Direito Internacional Publico 50 (8th ed. 1968). As pointed out by $M$. Ganji, International Protection of HuMAN RIGHTS 14-15 (1962) [hereinafter cited as GANJI, and by Reisman, $\mathrm{Hu}$ manitarian Intervention to Protect the Ibos, in HuMANITARIAN INTERVENTION AND THE UNITED NATIONS 167, 179 n.42 (R. Lillich ed. 1973) [hereinafter cited as Reisman], the term dictatorial does not necessarily require the actual use or threat of armed forces to allow an interference to be considered intervention, but can be taken to include other modalities of coercion as well. Nevertheless, this article will be primarily concerned with armed intervention.

5. See, e.g., Prime Minister Gandhi's statement in the Indian Parliament, May 24, 1971, cited in Nanda, Self-Determination, supra note 1, at 334 \& n.94; Prime Minister Gandhi's statement in The Motherland (New Delhi), Dec. 5, 1971, at 2, col. 1., cited in Nanda, Critique, supra note 1, at 65 \& n.95.

6. A possible explanation for India's reluctance to invoke formally the theory of humanitarian intervention in what appears to have been an almost perfect setting to do so, may have been its desire to avoid inconsistency between its course of action in the Bangladesh situation and its previous position in theoretical debates in the United Nations, where it apparently favored a strict interpretation of articles $2(4)$ and 51 of the Charter, thereby rejecting any additional exceptions to the flat prohibition of the threat or use of force regardless of motive. See, e.g., Statement by Mr. Krishna Rao (India), Special Committee on Principles of International Law Concerning Friendly Relations and Co-Operation Among States (Spec. Comm. on Fr. Rel.), 19 U.N. GAOR, U.N. Doc. A A.C. 119/S.R.29, at 13 (1964). 
operation raises is whether the present state of international law, as modified by the U.N. Charter, still permits unilateral resort to force in order to remedy a situation of large-scale deprivation of the most fundamental human rights, committed by a State against its own nationals.

In view of the serious doubts recently expressed by various scholars as to the existence of a "right" to intervene for humanitarian purposes as a generally recognized principle of customary international law (even in the pre-Charter period ${ }^{7}$ ), it will be necessary to analyze this particular contention before assessing the eventual survival of the doctrine in spite of the U.N. Charter prohibition of State-initiated force.

\section{The Traditional Doctrine of Humanitarian Intervention: State Practice}

Despite such early precedents as the Crusades, several of

7. Lauterpacht stated that: "The doctrine of humanitarian intervention has never become a fully acknowledged part of positive international law." Lauterpacht, The Grotian Tradition in International Law, 23 BRIT. Y.B. INT'L L. 46 (1946). But see note 125 infra and accompanying text. Compare Waldock, The Regulation of the Use of Force by Individual States in International Law (Hague Academy of International Law), 81 REcuen DES Cours 455, 461 (1952) [hereinafter cited as Waldock], who fails to mention humanitarian intervention in his list of traditional grounds of justification for intervention. See also J. BrIerLy, THe LAW of Nations 403 (6th ed. H. Waldock 1966) [hereinafter cited as BRIERLY]; GANJI, supra note 4, at 42; R. RedSLOB, TRAITE DE DRoIT DES GeNs 258 (1950) [hereinafter cited as RedsLob]; Franck \& Rodley, After Bangladesh: The Law of Humanitarian Intervention by Military Force, 67 АM. J. INT'L L. 275, 277 ff., 299 \& 302 (1973) [hereinafter cited as Franck \& Rodley]; Humphrey, Foreword, in HUMANITARIAN INTERVENTION, supra note 4, at VII; Marshall, Comment, 3 INT'L LAWYer 435 ff. (1969). Contra, D. BowetT, SELF-DEFENSE IN INTERNATIONAL LAW 95 (1958) [hereinafter cited as BoweTT]; L. Cavare, Le Droit Internattonal Public Positif 632 (3d ed. 1969); 1 P. Guggenheim, Traite de Droit International Public 289 (1953); A. Thomas \& A. Thomas, The Dominican Republic Crisis 1965, at 19-20 (IXth Hammarskjöld Forum 1967) [hereinafter cited as Thomas \& THomas]; Aronéanu, L'Intervention d'Humanité et la Déclaration Universelle des Droits de l'Homme, 33 Revue de Drotr International, de Science Diplomatique et Polmitiue 126, $128 \mathrm{ff}$. (1955) [hereinafter cited as Aronéanu]; de Nova, The International Protection of National Minorities and Human Rights, 11 HowarD L. J. 274 (1965); Lillich, Forcible Self-Help to Protect Human Rights, 53 IowA L. Rev. 325, 326 (1967) [hereinafter cited as Lillich, Self-Help]; Lillich, Intervention to Protect Human Rights, 15 MCGill L. J. 205, 209 ff. (1969) [hereinafter cited as Lillich, Intervention]; McDougal \& Reisman, Response, 3 INT'L LAWYER 438 ff (1969); Röling, On Aggression, on International Criminal Law, on International Criminal Jurisdiction (Part I), 2 NEDERLANDS TIJDSCHRIFT VOOR INTERNATIONAAL RECHT 167, 177 (1955) [hereinafter cited as Röling]. 
which could be considered humanitarian interventions, or the 16 th and 17 th century religious wars, ${ }^{8}$ it seems that the institution of humanitarian intervention is in fact largely a creation of the latter part of the 19th century. This is certainly true so far as State practice explicitly referring to this justification is concerned. Earlier instances of humanitarian intervention are too closely tied with a feeling of religious solidarity to allow them to be classified as genuinely humanitarian.

A large number of cases have occurred in which States in the 19th and early 20th century allegedly intervened on behalf of the local populations in other States. Examples include the United States' interventions in Cuba at the end of the 19th century, ${ }^{9}$ and the protests by the European Major Powers against the cruel treatment of political prisoners in Morocco in the beginning of the 20th century. ${ }^{10}$ These cases seem to lack either a clear humanitarian motive or the highly coercive character of an armed intervention. ${ }^{11}$ Therefore, the analysis of pre-Charter precedents of

8. For examples of interposition by sovereigns in favor of religious minorities in other States, see $1 \mathrm{R}$. PHILlimore, Commentaries UPON INTERNational Law 621 et seq. (3d ed. 1879).

9. But see Reisman, Humanitarian Intervention, supra note 4, at 182-83. For the official U.S. justification for the first of this series of interventions, see President Grant's Message to the U.S. Congress, Dec. 7, 1874, cited in W. MaNNing, Commentaries on the Law of Nations 97, n. $\dagger$ (rev. ed. S. Amos 1875) [hereinafter cited as Manning]. See generally $6 \mathrm{~J}$. MOORE, Digest of INrERNATIONAL LAw 211 ff. (1906) [hereinafter cited as MOORE]; de Lapradelle, Chronique sur les Affaires de Cuba, 1 Revue de Droit PUblique et de ScIence Politique en France et a L'Etranger 74 (1900) [hereinafter cited as de Lapradelle]; Lefur, Chronique sur la Guerre Hispano-Américaine, 5 Rev. GeN. Dr. INT'L PUBL. 665 (1898). For a summary of the U.S. involvement in Latin America from the Spanish-American War to the creation of the Organization of American States, see H. DE VRIES \& J. ROdRIGUeZ-Novas, THE LAW OF THE AMERICAs 16-17 and 20 (1965).

10. See Rougier, Chronique des Faits Internationaux, 17 REv. GEN. DR. INT'L PubL. 62, 98 ff. (1910). For a comprehensive treatment of 19th and early 20th century instances of humanitarian "intervention," both armed and diplomatic, see E. Stowell, INTERVENTION IN INTERNATIONAL LAW 63-316 (1921) [hereinafter cited as StowELx].

11. GaNJI, supra note 4 , at $41, \mathrm{n} .124$. Instances of peremptory demands by Major Powers, as occurred quite frequently in that period, should not be summarily discarded as not amounting to intervention. Often backed by an implicit threat of military or other measures, in case satisfaction was not given, they could be almost as coercive as actual armed intervention and retain a particular relevance as precedents in view of the prohibition in the U.N. Charter of not only the use but also the mere threat of force. See U.N. CharTER, art. 2, para. 4. A good example of the threat to use force for humanitarian purposes is provided by the peremptory demands of France and Great Britain, backed by 
forceful humanitarian intervention must be restricted to the notorious cases in Eastern Europe. ${ }^{12}$

\section{A. Intervention in Greece (1827-1830)}

As a result of the numerous massacres perpetrated in previous years by the Sublime Porte, France, Great Britain, and Russia concluded the Treaty of London on July 6, 1827. In this treaty they resolved unilaterally to combine their efforts to put an end to the bloodshed in Greece and proposed a limited local autonomy for the region within the Ottoman Empire. Upon rejection of their proposal by the Turkish government, the three Major Powers undertook an armed intervention which on September 14, 1829, resulted in the a posteriori acceptance by the Porte of the provisions of the 1827 Treaty of London, and in the independence of Greece in 1830.

In his International Protection of Human Rights, Ganji contends that this intervention provides only a very limited precedent of humanitarian intervention, insofar as the armed intervention against Turkey was mainly carried out by Russia. It was his opinion that Russia could rely on certain concessions it obtained from the Sultan by the 1774 Treaty of Kutchuk-Kainardji for the protection of the Christian religion in the Ottoman Empire. ${ }^{13}$

It seems, however, that this approach is far too negative in view of the rather revolutionary character of the course of action of the European Powers, since this was an era where the absolute personal jurisdiction of the Prince over his subjects was still largely regarded as a central attribute of sovereignty. It appears clear that this course of action could certainly not have been envisaged as early as $\mathbf{1 7 7 4}$, nor assented to beforehand by Turkey in the Treaty. It is indeed doubtful whether Russia could justify its armed intervention on the Treaty, for article VII merely provided that:

The Sublime Porte pledges to protect the Christian religion and its churches constantly; and also it grants permission to the Ministers of the Imperial Court of Russia to make representations in all circumstances, in favor of the new church

the mobilization of their fleets, to the King of the Two Sicilies in 1856. Rougier, supra note 3 , at 475 .

12. The facts of these cases are taken primarily from GaNJI, supra note 4, at 22 ff.; Stowell, supra note 10, at 63 ff.; Rougier, supra note 3, at 473. See also J. Mattiott, The Eastern Question (2d ed. 1930).

13. GaNJI, supra note 4, at 23-24. 
in Constantinople . . . as well as in favor of those who service it . . . ${ }^{14}$

Furthermore, as far as participation in the intervention by France and Great Britain is concerned, it is even clearer that this provision could not provide a treaty-basis, since the Treaty was a purely bilateral agreement between Turkey and Russia.

Finally, in the 1827 Treaty of London the Major Powers themselves indicated that their action was dictated "no less by sentiments of humanity, than by interest for the tranquilty of Europe;"15 thus invoking, for the first time in history, humanitarian concern as a justification for intervention.

\section{B. Intervention in Syria (1860-1861)}

Following the massacre of thousands of Christians in Syria by the local Moslem population with the complicity of the Turkish authorities, France, Great Britain, Prussia, and Russia met with Turkey at the Conference of Paris and signed a Protocol on August 3,1860 . In this agreement they gave France a mandate to intervene in Syria to restore order in the area. Six thousand French troops were sent to Syria, and on October 5, 1860, an International Commission was created. This commission adopted a set of rules regulating the French presence in Syria and, on June 9, 1861, a new Constitution for the Lebanon region. Subsequently, the French force, having completed its mission, left Syria.

Apparently, not too much importance should be given to the fact that formally this operation did not amount to an intervention since the Sultan gave his consent to the activities of the Concert of Europe by signing the Protocol of Paris. ${ }^{16}$ One can reasonably

14. 1774 Treaty of Peace and Friendship Between Turkey and Russia (Kutchuk-Kainardji), 2 G. DE MARTENS, ReCueIL Des Trartes 287-322 (2d ed. 1817), cited in GANJI, supra note 4, at 18 (emphasis added). Articles XVII and XXIII of the same treaty contain similar pledges. This persecution of Christians in Turkey constituted a violation of these treaty commitments and, under the then valid rule of legal resort to force for enforcement of treaty obligations, would have justified Russian self-help in the form of intervention However, the inclusion in article VII of a specific permission for the Russian agents in Turkey to make representations - and nothing more-could, $e$ contrario, indicate that other, more drastic measures by Russia in case of violation of these specific human rights provisions had not been envisaged nor consented to in the treaty.

15. Treaty of London, July 6, 1827, 14 Brit. \& Foreign State Papers 633 (1826-1827), cited in GANJI, supra note 4, at 22.

16. "When consent is given by a state to foreign action of an interventionary character, in reality there is no intervention." THOMAs \& THOMAs, supra note 7 , at 22 . Although strongly opposed to any form of intervention for any 
question the validity of that consent, for it seems clear that Turkey assented to the French expedition "only through constraint and a desire to avoid worse."17

Similarly, one should not place too much emphasis on the official ground of justification invoked by the Major Powers: article IX of the General Treaty of Paris of March 30, 1856, concluded between Austria, France, Great Britain, Prussia, Russia, Sardinia, and Turkey. The first paragraph of this article merely takes note of the promulgation by the Sultan, in February 1856, of the Firman Hatti-Sherif. This document was a domestic legislative instrument of utter vagueness in which he affirmed his generous intentions towards all his subjects without distinction as to religion or race. The second paragraph of the same article specifically provides that this reference to the Firman:

[C]ould not, in any circumstance, give the right to the said

Powers to intervene either collectively, or separately, in the relations of his Majesty the Sultan with his subjects, nor in the internal administration of his Empire. ${ }^{18}$

As Rougier, a contemporary, observes: "Their right to intervene cannot be based on this text, but only on the fact that the Turkish government had allowed six thousand of its subjects to be massacred." 19 And he concludes: "The Syrian intervention was thus a humanitarian intervention, and not an intervention aimed at enforcing execution of a convention." 20

reason whatsoever, Mencer reaches a similar conclusion based on a formalistic logical reasoning:

[S]i l'admissibilité de l'intervention humanitaire est conditionnée par un assentiment donné préalablement et expressément dans un traité, . . . d'une part .... il ne s'agit pas d'une imposition de volonté au vrai sens de $c e$ terme, d'une ingérence entreprise contre la volonté de l'Etat respectif (puisqu'il ne s'agit point d'une intervention au sens des règles de droit), et d'autre part, il s'y applique la règle selon laquelle il est possible.... de donner, par la voie d'un traité valide et librement conclu, l'assentiment à toute ingérence et non seulement à l'intervention humanitaire.

Mencer, La Coéxistence Pacifique et le Principe de la Non-Intervention, 1 Boletin Mexicano de Derecho Comparado 314 (1969) [hereinafter cited as Mencer].

17. Stowell, supra note 10 , at 66 . Even those scholars who question the existence of a customary international law right of bumanitarian intervention feel compelled to concede this point: "The state practice justifies the conclusion that no genuine case of humanitarian intervention has occurred, with the possible exception of the occupation of Syria in 1860 and 1861." I. BROWNLIE, INTERNATIONAL LAW AN THE USE OF FORCE BY States 340 (1963) [hereinafter cited as BroWnLIE]. See also GANJI, supra note 4, at 26 \& 28.

18. 46 Brit. \& Foreign State PAPERS 12 (1855-1856), cited in GaNJi, supra note 4 , at 20 .

19. Rougier, supra note 3 , at 474.

20. Id., at 474 n.4. It would seem that this provision of the Treaty of 


\section{Intervention in the Island of Crete (1866-1868)}

As a result of several years of persecution and discrimination at the hand of the Turkish authorities in the island, the Christian population of Crete broke into open rebellion against the Ottoman rulers in 1866 and proclaimed enosis (union) with Greece. Following the brutal repression of the revolt by the Porte, the European Powers, with the exception of Great Britain, made various pressing demands upon the Sultan, ranging from Turkish consent to an on-the-spot investigation by an International Commission of Inquiry to free elections and independence of Crete. None of these proposals were accepted by the Porte, but upon British advice, the Sultan promulgated a new Constitution for the island, ameliorating the position of the Christians. The Sultan's reaction thus avoided the armed intervention which had been envisaged by the European Powers following his initial refusal.

In this particular instance, it seems that the diplomatic interposition of the European Powers could, as Ganji contends, ${ }^{21}$ be based on the violation by Turkey of specific treaty obligations. The Powers invoked in justification various provisions of the London Protocol of February 20, 1830, whereby France, Great Britain, and Russia guaranteed the Greek independence, as well as article IX of the 1856 Treaty of Paris. While the latter, as has already been indicated, could not possibly provide a treaty basis for an intervention, albeit a purely diplomatic one, it seems that the tripartite London Protocol could justify, on conventional grounds, the nonforceful intercessions of France and Russia. This is true since the Protocol, as adhered to by Turkey in a note of April 24, 1830, ${ }^{22}$

Paris, if it has to have any relevance at all in this case, should be interpreted as a pledge by the Great Powers to refrain from intervening, rather than as allowing them to intervene. Contra: GaNJI, supra note 4, at 30-31, who makes the rather controversial statement that the firman of the Sultan has to be considered an integral party of the treaty since several European Powers would have "hesitated" to accept the treaty, had those guarantees for the non-Moslem population not been given by Turkey. And he concludes:

The principle of non-intervention in the second paragraph of article IX was embodied for the sole purpose of providing that, as long as the

Sultan was acting in good faith in implementing the Firman, the Euro-

pean powers were to abstain from intervening. . . .

Id. (emphasis added).

21. GANJI, supra note 4, at 29.

22. 17 Brit. \& Foreign State Papers 203 (1827-1830), cited in GanJi, supra note 4 , at 28. 
contained a declaration by France, Great Britain, and Russia to the extent that:

[E]ach Allied Power ... would consider it its duty to interpose its influence with the Porte, so as to ensure to the inhabitants of the above mentioned Isles [Candie ${ }^{23}$ and Samos], protection against oppressive and arbitrary acts. ${ }^{24}$

Whether this document would have equally justified the armed intervention once envisaged by the European Powers, is much more doubtful. Furthermore, it leaves unaltered the finding that the Protocol could not provide a conventional ground for the participation of those European Powers not parties to it (Austria, Italy, and Prussia).

\section{Intervention in Bosnia, Herzegovina, and Bulgaria (1876-1878)}

Following a formal declaration of war by Serbia and Montenegro against the Porte on June 30, 1876, in support of the oppressed Christian populations of Bosnia, Herzegovina, and Bulgaria, the European Powers met with Turkey at the Conference of Constantinople. When the Sultan refused to agree to the establishment of an International Commission to control the implementation of the reforms he proposed to carry out in the Balkan, Austria-Hungary, France, Germany, Great Britain, Italy, and Russia met separately and agreed upon the London Protocol of March 31, 1877. In this Protocol, the European Powers reaffirmed their concern for the Christians in the area and indicated their intention to watch the fulfillment of the reform promises made by the Porte in the 1856 Treaty of Paris. They also stressed their determination to take all necessary measures in the event that the Sultan failed to improve the condition of his Christian subjects in the Balkan.

After rejection of the Protocol by Turkey on the grounds of domestic jurisdiction in general, and of the restrictive terms of article IX, paragraph 2, of the 1856 Treaty of Paris in particular, ${ }^{25}$ Russia declared war upon the Porte. Subsequently, the other Major Powers declared their neutrality and, on February

23. This is the ancient french name for Crete used in the treaty.

24. 17 Brit. \& Foreign State PaPers 203 (1827-1830), cited in GanJi, supra note 4, at 28.

25. See authority cited in note 18 supra and accompanying text. 
19,1878 , the war came to an end with the signing of the Preliminary Treaty of San Stefano.

Following negotiations between Austria-Hungary, France, Germany, Great Britain, Italy, Russia, and Turkey at the Congress of Berlin, the 1878 Treaty of Berlin was adopted. It provided for limited local autonomy of a Christian government under Turkish suzerainty in Bulgaria, and for the occupation of Bosnia and Herzegovina by Austria-Hungary. It further reaffirmed the independence of Montenegro, Rumania, and Serbia, and imposed specific obligations of religious and racial non-discrimination upon Turkey, both in the Empire itself, and in the autonomous principality of Bulgaria. ${ }^{28}$

The declarations of war by Serbia and Montenegro were officially justified by humanitarian solidarity with the oppressed populations in the neighboring countries. On the other hand, the demands by the European Powers, as well as the war waged by Russia, were once more formally based upon an invocation of article IX of the 1856 Treaty of Paris. As has been indicated earlier, this provision could not provide a valid ground for intervention, armed or non-armed. Again, it seems that this is a case which could only be justified by the underlying humanitarian concern of the Major Powers, as was clearly alluded to in the note of the Russian government to the Sublime Porte of November 13, 1876:

His Imperial Majesty does not want war . . . but is determined not to hestiate as long as the principles that have been recognized as equitable, humane, necessary by the whole of Europe . . . have not received full execution in effective guarantees. ${ }^{27}$

\section{E. Intervention in Macedonia (1903-1908, 1912-1913)}

Following increasingly intense sporadic insurrections in Macdonia from 1893 onward, and more directly in response to the atrocities committed by the Ottoman troops in mid-1903, AustriaHungary and Russia, acting as mandatories of the Concert of Europe, strongly urged the Porte to accept the Mürzsteg Program.

26. 69 Brit. \& Foreign State Papers 753 (1877-1878), cited in GanJI, supra note 4 , at $20-21$.

27. 47 Brit. \& Foreign State Papers 321 (1856-1857), cited in Ganji, supra note 4, at 31 (emphasis added). 
This program included a series of far-reaching reform proposals for Macedonia, the introduction of which was to be controlled by Austrian and Russian diplomatic agents. Impressed by the European unity and determination, the Sultan, late in 1903, gave his consent to the Program.

After the outbreak of the Young Turk Revolution in June, 1908, the Powers withdrew their control agents, as the reformist ideology of the new rulers made it appear likely that application of the Program would be continued and foreign supervision seemed to have become unnecessary. This hope was soon shattered when the new regime embarked on a program of intense "Turkification" of the Christian population of Macedonia. In view of this unexpected development, and particularly of the extreme brutality with which the "Turkification" was carried out, Bulgaria, Greece, and Serbia, "unable to tolerate any longer the sufferings of their brethren in Turkey," 28 declared war upon the latter. On May 30, 1913, after some seven months of fighting, this war came to an end with the conclusion of the 1913 Treaty of London, by which Turkey ceded the greater part of Macedonia for partition among the Balkan Allies.

In 1903 , the peremptory demands by Austria-Hungary and Russia on behalf of the Concert of Europe were, again, formally based on the provisions of article IX of the 1856 Treaty of Paris, and on various parts of the 1878 Treaty of Berlin. As indicated above, article IX lacks relevance. However, reference to the latter treaty is more convincing. It is clear that articles 23 and 62 of the 1878 treaty imposed specific obligations on Turkey regarding the treatment of its non-Moslem subjects ${ }^{29}$ and as a result the right of intervention to secure compliance with conventional obligations was generally accepted under international law at that time. ${ }^{30}$

It is noteworthy, that the three Balkan Allies, although not able to invoke any breaches of direct treaty commitments since they were not parties to, but only subjects of, the Berlin Treaty, did not hesitate to resort to force. Significantly, their justification for their course of action was their humanitarian concern with the treatment inflicted upon the Macedonian people. ${ }^{31}$

28. Note Verbale to the British Government, 106 BRIT. \& Foreign State PAPERS 1059-60 (1913), cited in GANJI, supra note 4, at 36.

29. See authority cited in note 26 supra and accompanying text.

30. See, e.g., Rougier, supra note 3 , at 474.

31. See authority cited in note 28 supra and accompanying text. 


\section{The Pre-Charter Doctrine}

\section{A. The Question of Principle: Is Humanitarian Intervention Permissible under International Law?}

While rather vague statements, to the extent that a sovereign is entitled to intervene on the basis of religious solidarity in the internal affairs of another when the latter mistreats his own subjects beyond the limits of what seems acceptable, can be found as early as the writings of St. Thomas Aquinas, it is only later ${ }^{32}$ that this doctrine appears to have been secularised in the doctrine of lawful assistance to a people struggling against tyranny.

Albeit in general terms, Grotius accords his support to this view when he declares:

There is also another question, whether a war for the subjects of another be just, for the purpose of defending them from injuries by their ruler. Certainly it is undoubted that ever since civil societies were formed, the ruler of each claimed some especial right over his own subjects. . . . [But] ... [i]f a tyrant ... practices atrocities towards his subjects, which no just man can approve, the right of human social connexion is not cut off in such case. ${ }^{33}$

Vattel, on the other hand, seems not to have been completely able to resolve what Mosler called "the problem of the friction between Sovereignty and the Law of Nations."34 First, he observes:

The sovereign is the one to whom the Nation has entrusted the empire and the care of government; it has endowed him with his rights; it alone is directly interested in the manner in which the leader it has chosen for itself uses his power. No foreign power, accordingly, is entitled to take notice of the administration by that sovereign, to stand up in judgment of his conduct and to force him to alter it in any way. If he buries his subjects under taxes, if he treats them harshly, it is the Nation's business; no one else is called upon to admonish him, to force him to apply wiser and more equitable

32. For an analysis of the writings of early scholars on this point, see Esmein, La Théorie de l'Intervention Internationale chez Quelques Publicistes Français du XVIème Siècle, 24 Nouvelle RevUe Historique dE Droit Francais et Etranger $563(1900)$. See generally A. Dunning, Political Theories FROM LUTHER TO MONTESQUIEU (1905).

33. H. Grotius, 2 De Jure Belli est PaCis, Ch. XXV, at 438 (Whewell transl. 1853).

34. H. Mosler, Die Intervention im Völkerrecht 3 (1938). 
principles. $^{35}$

Vattel immediately qualifies this general statement by the apparently contradictory contention that:

[I]f the prince, attacking the fundamental laws, gives his people a legitimate reason to resist him, if tyranny becomes so unbearable as to cause the Nation to rise, any foreign power is entitled to help an oppressed people that has requested its assistance. ${ }^{36}$

Once the middle of the 19th century is reached, the decline of the Law of Nature and the rising of the contradictory values of nationalism, sovereign independence and nonintervention on the one hand, and humanitarianism on the other hand, influences the thinking on the subject. The statements become clearer; the scholars take positions; and, in general, a dichotomy appears between the champions of an expanding nonintervention norm and those who favor a more flexible rule permitting intervention on various grounds.

Kant, for instance, illustrates the first approach when he states:

In general . . . the bad example given by a free person to the others does not result in any damage to the latter. One could thus not intervene for that motive alone without oneself giving an example of the very scandal one is trying to avoid and without endangering the autonomy of all States. ${ }^{37}$

Mamiani, the leader of the Italian nonintervention or neonationalist school, is quoted by Carnazza-Amari as saying:

The actions and the crimes of a people within the limits of its territory do not infringe upon anyone else's rights and do not give a basis for a legitimate intervention. Truely, what positive right of the other peoples does one infringe upon? Have you ever heard it said that the law requires that one be only confronted with good example . . . .38

Carnazza-Amari himself summarizes the extreme position of the Italian school as follows:

Neither can one justify intervention in the case where the

35. 2 E. De Vattel, Le Droit des Gens, Ch. IV, para. 55 (Pradier-Fodéré ed. 1863).

36. Id., para. 56.

37. E. Kant, Essai Philosophique sur la Paix Perpetuelle, art. V, cited in Rougier, supra note 3, at 482 n.1.

38. 1 Carnazza-amari, Traite de Droit International en Temps DE PaIX 557 (Montanari-Revest transl. 1880). 
local government does not respect the most elementary laws of justice and humanity. ${ }^{39}$

This rigid noninterventionism was not particular to Italy. In France, for example, Pradier-Fodéré states:

The right to punish presupposes sovereign power, on the part of the one exercising it, over the one against whom it is being exercised. ... While the sovereign can sanction crimes that disturb the social and political order of the people he governs, his authority expires at the border of the national territory, and he lacks the right to punish criminals whose acts would have affected public order abroad. Accordingly, if he lacks this right as against criminals that would be mere individuals, a fortiori he cannot be so preposterous as to exercise it as against a State and a whole people. ${ }^{40}$

And he concludes:

This [humanitarian] intervention is illegal because it constitutes an infringement upon the independence of States, because the powers that are not directly, immediately affected by these inhuman acts are not entitled to intervene. If the inhuman acts are committed against nationals of the country where they are committed, the powers are totally disinterested. The acts of inhumanity, however condemnable they may be, as long as they do not affect nor threaten the rights of other States, do not provide the latter with a basis for lawful intervention, as no State can stand up in judgment of the conduct of others. As long as they do not infringe upon the rights of the other powers or of their subjects, they remain the sole business of the nationals of the countries where they are committed. ${ }^{41}$

Heffter, in Germany, seems to espouse the doctrine of the Italian school when he writes:

As far as no imminently threatening violations of the law

39. Id., at 555 (emphasis added). See also E. Cimbali, IL Non-Intervento-Studio di Diritto InTERnazionale Universale 262 (1889) and Tanoviceano, Le DroIt INTERNATIONAL de L'INTERVENTION 12-13 (1884). Strangely enough, the Italian school, while absolutely condemining intervention for humanitarian purposes as such, strongly supported the right of States to assist other nations struggling for independence. $I d$., at 89. This approach is similar to the current double standard applied by the United Nations in dealing with human rights questions involving self-determination of colonial peoples, as opposed to human rights violations in a non-colonial setting.

40. 1 P. Pradier-fodere, Traite de Drott International Europeen et AMERICAIN 655 (1885).

41. Id. at 663. See also DE FlOECKHER, DE L'INTERVENTION EN DroIt INTERNATIONAL 18-19 (1896). 
or [actual] perils are involved, even the most outrageous inequities, that are committed in a State, cannot provide another [state] with a legal ground for unilateral intervention against the former; for no State is entitled to pass judgment upon another. ${ }^{42}$

The Latin American scholars, traditional champions of the nonintervention principle in view of their experience as victims of repeated foreign intervention, took the same inflexible approach. For instance, Pereira states:

Internal oppression, however odious and violent it may be, does not affect, either directly or indirectly, external relations and does not endanger the existence of other States. Accordingly, it cannot be used as a legal basis for use of force and violent means. ${ }^{43}$

Likewise in the Anglo-American literature, some resistance against the notion of a permissible intervention for humanitarian purposes can be found in this period. Halleck, for example, writes:

We have stated ... that when a state is desolated by protracted civil war, foreign interference, by way of pacific mediation, in order to stay the effusion of blood, is not only justifiable, but is sometimes a duty imposed by humanity. But will the general interests of humanity justify interference to the extent of war of intervention? ${ }^{44}$

Quoting Phillimore, he answers this question negatively:

This ground of intervention . . . urged on behalf of the general interests of humanity, has been frequently put forward,

42. A. HefFTer, Das Europärsche VölKerRecht der GegenWart aUf DER BISHERIGEN GRUNDLAGEN 109-10 (7th ed. 1882) [hereinafter cited as HeFFTER]. He approves, however, the Italian support for the right of assistance to peoples involved in a war of independence:

Eine weitere Befugniss, nämlich zu einer thatlichen Cooperation eröf-

fnet sich wenn in einem Staate ein innerer Krieg wirklich ausgebrochen ist und ein anderer Staat von dem im Recht befindlichen aber widerrechtlich bedrängten Theile um Hilfe angerufen wird. Es ist schon das Recht jedes einzelnen Menschen, dem widerrechtlich Gekränkten zu seiner und seines Rechtes Erhaltung beizustehen; es muss auch das Recht der Staaten sein.

$I d$., at 110. Even more resolute in his condemnation of humanitarian intervention is Gareis: "Von der Anwendung des 'Prinzips der Nichtintervention' allgemein eine Ausnahme zu Gunsten der Humanität zu machen ist unzulässig. . . ." K. GAREIS, INSTITUTIONEN Des VölKeRREchts 96 (2d ed. 1901). See also H. STRAUCH, ZUR INTERVENTIONSLEHRE 13-14 (1879).

43. 1 L. Pereira, Principios de Direito Internacional 97-98 (1902), cited in $1 \mathrm{H}$. Accioly, Traite de Droit International Public 283 (Goulé transl. 1940) [hereinafter cited as AccioLY].

44. H. Halleck, INTERNational LAW 340 (1861). 
and especially in our own times, but rarely, if ever, without others of greater and more legitimate weight to support it. ... As an accessory to others, this ground may be defensible, but, as a substantive and solitary justification of intervention in the affairs of another country, it can scarcely be admitted into the code of international law, since it is manifestly open to abuses, tending to the violation and destruction of the vital principles of that system of jurisprudence. ${ }^{45}$

More typically, however, a substantial body of writers espouse a double-level permissibility by refusing to grant humanitarian motivation the character of a formal legal justification of intervention, while at the same time recognizing that a violation of the nonintervention principle, though technically a breach of the law, might in certain circumstances be not only excusable, but even commendable. Bernard, for instance, states: "The law . . . prohibits intervention. . . . Nay, there may even be cases in which it becomes a positive duty to transgress it." ${ }^{46}$ Specifically referring to humanitarian considerations, Harcourt argues: "Intervention is a question rather of policy than of law, and when wisely and equitably handled ... may be the higher policy of justice and humanity." 47

Another tendency in this period is to accept a limited right of humanitarian intervention, restricting its lawful application either to very specific circumstances or to situations involving certain categories of States only.

An example of the former type of qualification is provided by Creasy when, acknowledging that "intervention may be justifiable, and even a duty, in certain exceptional cases," 48 he restricts the legality of humanitarian intervention to those cases only:

[W] here we intervene in behalf of a grievously oppressed people, which has never amalgamated with its oppressors as one nation, and which its oppressors have systematically treated as an alien race, subject to the same imperial authority, but in other respects distinct ... [or] where the King, or dominant party of a nation keeps up, in defiance

45. 1 R. Phillimore, On International Law, paras. 394 ff., cited in HalLECK, supra note 44 , at 340 .

46. M. Bernard, On the Principle of Non-intervention 33-34 (1860).

47. V. HARCOURT (HISTORICUS), LETTERS ON SOME QUESTIONS OF INTERNATIONAL LAW 14 (1863) (emphasis added). Compare the modern approach to retaliation of Falk and Bowett, note 194 infra. See also note 193 infra and accompanying text.

48. E. Creasy, First Platform of International Law 303 (1876). 
of the State's fundamental Laws, a mercenary army of regular troops, especially if carefully organized and officered by men who are of creed, of politics, and of feelings alien from those held by the great majority of the population, and where, by this being done, all effective manifestations of the popular will, and the formation of a truly national force are rendered utterly impossible, . . . ${ }^{49}$

thus requiring a racial element to transgress the internal matter aspect of the treatment by a sovereign of his own subjects. ${ }^{50}$

More common, however, was the notion that the right to intervene for humanitarian motives was to be restricted to the relations between "civilized" and "non-civilized" nations.

de Martens, for instance, argues that:

Vis-a-vis non civilized nations . . intervention by the civilized powers is in principle legitimate, when the Christian population of those countries is exposed to persecutions or massacres. In those circumstances, it is justified by common religious interests and humanitarian considerations. . . . These motives are not applicable to the relations between civilized powers . . .51

By so arguing, he links the notion of humanity with that of religious solidarity and with the existence of different categories of States. Often without the religious connotation, similar opinions can be found in the works of a number of jurists of this period. ${ }^{52}$

Although their pronouncements usually remain vague and are often qualified by considerations of Major Power supremacy and outspoken predilection for collective action, from the 1860 's on, writers seem increasingly won to the idea of the lawfulness

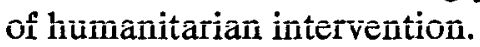

Following some rather revolutionary conceptions by Heiberg, ${ }^{53}$ revealed as early as 1842 , and shortly after the publication of Berner's Deutsche Staatswörterbuch, ${ }^{54}$ Dana's edition of Whea-

49. Id., at 303-05.

50. Compare the current "double standard" generally applied by the United Nations regarding human rights violations in accordance with the presence or absence of a racial or colonial implication.

51. 1 F. de Martens, Traite de Droit International 398 (Léo transl. $1883)$.

52. See BERNARd, supra note 46 , at 7 ; STRAUCH, supra note 42 , at 14 ; GaREIS, supra note 42 , at 85 . For a critique of this approach, see KEBEdGY, INTERVENTION 85-86, cited in STOWELL, supra note 10 , at 65, n.14.

53. Heiberg, Das Prinzip der Nichtintervention in Seiner Beziehung AUF DIE AUSSERE UND INNERE ORganisation DES STAaTS 14-15 (1842).

54 Berner, Deutsche, StaAtswörterbuch 341 (1860). 
ton's Elements of International Law notices in 1866 that:

The interference of the Christian powers of Europe, in favor of the Greeks . . . affords a further illustration of the principles of international law authorizing such an interference ... . where the general interests of humanity are infringed by the excesses of a barbarous and despotic government. ${ }^{55}$

Referring primarily to civil strife situations, Bluntschli observes in 1874:

One is authorized to intervene to ensure respect for the individual rights that have been recognized as necessary . . . whenever they happen to be violated in the struggles between citizens of a single state. ${ }^{56}$

Qualifying his position by the restriction that "[i]nterference on the score of humanity or of religion can be justified only by the extreme gravity of the case," ${ }_{57}$ Woolsey, in 1876, unambiguously asserts that:

[I]nterference ... can be justified ... on ... the ... following [ground]: ... [t]hat some extraordinary state of things is brought about by the crime of a government against its subjects. ${ }^{58}$

That same year, in a letter addressed to Rolin-Jacquemyns, Arntz developed the theory as follows:

When a government, even acting within the limits of its rights of sovereignty, violates the rights of humanity, either by measures contrary to the interests of other States, or by excessive injustice or brutality which seriously injure our morals and civilization, the right of intervention is legitimate. For, however worthy of respect the rights of sovereignty and independence of States may be, there is something even more worthy of respect, namely the law of humanity, or of human society, that must not be violated. In the same way as within the State freedom of the individual is and must be restricted by the law and the morals of the society, the individual freedom of the States must be limited by the law of human society. ${ }^{59}$ 1866).

55. H. Wheaton, Elements of International LaW 113 (8th ed. R. Dana

56. J. Blüntschli, Le Drort International Codffie 272, art. 478 (Lardy transl. 1874). (1876).

57. T. WOOLSEY, INTROduction to THE Study OF INTERNational LAW 73

58. Id., at 57.

59. Lettre de $M$. Arntz, in Rolin-Jacquemyns, Note sur la Théorie du Droit 
And he concludes I recognize the right of intervention in an absolute way as against all States."

Some ten years later, Fiore, although basically a noninterventionist, ${ }^{61}$ articulates the doctrine further:

It is, indeed, unquestionable that, as a society cannot be imagined in the absence of laws, abidance by the natural laws of the society of States is of such capital importance for everybody's tranquilty that, if one of them 'was to be permitted to violate them with impunity, and the others were obliged to remain indifferent to that violation, without the right to prevent it, the society of States could not survive. $\ldots{ }^{62}$

Specifically regarding humanitarian intervention he concludes:

The violation of international law can also be a consequence of events occurring inside a State, and which results in the direct violation of international law. Let us assume, for instance, that a prince, in order to put down a revolution, violates all the generally recognized laws of war, has prisoners executed, authorises destruction, looting, arson, and encourages his supporters to commit those odious actions and others of the same kind; or, alternatively, let us suppose that it is the faction that [seized power] which engages in similar crimes. Inaction and indifference of other States would constitute an egocentric policy contrary to the rights of all; for whoever violates international law to the disadvantage of anybody, violates it not only to the detriment of the person directly affected, but as against all civilized States. ${ }^{63}$

The legal character, in the opinion of these writers, of the permissibility of humanitarian intervention is clearly apparent: For instance, de Lapradelle, commenting upon the U.S. intervention in Cuba, states:

Whereas it is true that States are sovereign, that sovereignty ... has its limits . . . in international law . . . in the fundamental rights of humanity. ${ }^{64}$

Despite similar views expressed in that same period by other

d'Intervention, 8 Revue de DroIt International et dE Legislation Comparee [REV. DR. INT'L \& LegisL. COMP.] 675 (1876).

60. Id.

61. Rougier, supra note 3 , at 482 n.1.

62. 1 P. Fiore, Nouveau Droit International Public 521-22 (Antoine transl. 1885).

63. Id., at 524-25.

64. de Lapradelle, supra note 9, at 75 (emphasis added). 
scholars ${ }^{65}$ as well as statemen, ${ }^{66}$ it is only after the turn of the century that one is able to witness what Mandelstam called "the victory of the principle of humanitarian intervention over the rigid dogma of nonintervention."67 Of particular importance for this development, together with the precedents set by State practice primarily in Eastern Europe, was the fundamental refusal of many authors to allot to State sovereignty the character of an $a b$ -

65. See, e.g., S. Amos, Political AND Legal Remedies fOR WaR 158 (1880) [hereinafter cited as AMOs]. "[G]ross acts of inhumanity . . . persisted in on either side... may, on grounds of humanity, properly precipitate intervention." Accord: Engelhardt, Le Droit d'Intervention et la Turquie, 12 Rev. DR. INT'L \& I.EGISL. COMP. 365 (1880):

A un point de vue plus large et en dehors des ingérences qu'autorisent d'une part le droit conventionnel proprement dit et d'autre part le droit international basé sur des maximes solennellement reconnues et communément observées, l'intervention peut être admise lorsqu'un Etat . . . se rend coupable d'une 'violation énorme' des droits de l'humanité.

Presumably as a result of the self-determination aspect of most precedents, a large number of scholars concentrate on situations involving civil strife when illustrating their plea in support of humanitarian intervention. For instance, Hall observes:

While however it is settled that as a general rule a state must be allowed to work out its internal changes in its own fashion ... intervention for the purpose of checking gross tyranny or of helping the efforts of a people to free itself is very commonly regarded without disfavour.

W. Hall, A Treatise of International LaW 265 (2d ed. 1884). See also A. Rivier, LeHrbuch DES VölkERREchts 233 (1899) [hereinafter cited as RIVIER]:

Als ein fernerer Fall, wo Intervention rechtmässig ist, wird auch derjenige angegeben, wo die Rechte der Menschheit von einer grausamen, barbarischen Regierung verletzt werden durch flagrante Ungesetzlichkeiten, Verfolgungen u.s.w., wo gewiss noch hinzuzufügen ist der Fall ähnlicher Gewältthatigkeiten von seiten einer revolutionären Faktion, welchen Namen sie auch tragen möge.

Compare Manning, supra note 9, at 97:

The only grounds on which interference with the affairs of a foreign State would now be held capable of justification are ... (2) the continuance of a revolutionary state of affairs in the foreign State under circumstances in which it seems highly probable that, without such interference, either public order can never be restored at all; or can only be restored after such sufferings to humanity and such injuries to surrounding States as obviously overbalance the general evil of all interference from without.

66. See, e.g., Statement by U.S. Secretary of State Fish cited in D. Gruber, Crisis DiplomacY 339 (1959):

[T] he general rule of non-intervention in the domestic affairs of other countries does not apply if the grievance adverted to is so enormous, as to impart to it, as it were, a cosmopolitan character, in the redress of which all countries, governments and creeds alike are interested.'

See also Statement of President McKinley (1898), cited in Reisman, supra note 4, at 182-83 and President Grant's Message to Congress cited in MaNNING, supra note 9.

67. Mandelstam, La Protection des Minorités (Hague Academy of International Law), 1 Recuell DES Cours 367, 391 (1923) [hereinafter cited as Mandelstam]. 
solute principle not susceptible of restrictions or exceptions. Consequently, nonintervention was seen as a flexible notion which could lawfully be disregarded for the defense of higher values in certain circumstances. ${ }^{68}$

In the period immediately preceding the first World War, it seems that the majority of the writers had been won to the idea of the legality of humanitarian intervention, ${ }^{69}$ and that only a few scholars, albeit notorious ones, continued to reject the validity of the doctrine. Apparently, most of them did so on the basis of doubts as to the actual integration of the theory in the generally accepted body of customary international law, rather than because of fundamental philosophical, ideological, or political convictions regarding absolute sovereignty and nonintervention. ${ }^{70}$

A minority appeared still troubled by the contradiction between these basic notions and their personal humanitarian feelings. Lawrence, for instance, tried to reconcile both by emphasizing the difference between law and policy, giving priority to the latter in exceptional circumstances:

68. See notes 94-96 infra and accompanying text. See generally Brocher de la Fléchère, Solidarité et Souveraineté, 26 REv. Dr. INT'L \& LEGISL. CoMP. 415 (1894).

69. For example, Basdevant urged that: "[L]'Etat qui ne remplit pas sa fonction de justice même à l'égard de ses nationaux perd son droit au respect et ... les autres puissances sont autorisées à substituer leur action à la sienne." Basdevant, Chronique, 11 Rev. Gen. Dr. INT'L PUBl. 110 (1904). In an often quoted passage, Borchard notes that:

[WThere a state under exceptional circumstances disregards certain rights of its own citizens, over whom presumably it has absolute sovereignty, the other states of the family of nations are authorized by international law to intervene on grounds of humanity.

E. Borchard, The Diplomatic Protection of Citizens Abroad 14 (1916) (emphasis added). See also L. Oppenheim, International Law 347 (1st ed. 1905); A. Pillet, Principes de Droit International Prive 171 (1903); Lingelbach, Intervention in Europe, 16 AnNals AM. ACAD'y PoL. \& Soc'l ScI. 25 (1900); Rougier, supra note 3; Moore, supra note 9, at $347 \mathrm{ff}$.

70. The following statment by Hodges typifies this position: "As regards an intervention undertaken in the cause of humanity there seems to be a divergence of opinion among the most prominent writers . . ." H. HODGES, THE DocTRINE OF INTERVENTION 87 (1915) [hereinafter cited as HODGEs]. With a view towards the evolution of international law, he optimistically concludes:

As the feeling of general interest in humanity increases, and with it a world-wide desire for something approaching justice and an international solidarity, interventions undertaken in the interests of humanity will also doubtless increase. ... We may therefore conclude that future public opinion and finally international law will sanction an ever Id. at 91 .

increasing number of causes for intervention for the sake of humanity. 
There is a great difference between declaring a national act to be legal, and therefore part of the order under which states have consented to live, and allowing it to be morally blameless as an exception to ordinary rules. ... An intervention to put a stop to barbarous and abominable cruelty is "a high act of policy above and beyond the domain of law." It is destitute of technical legality, but it may be morally right and even praiseworthy to a high degree. ${ }^{71}$

Hyde attempted to partially circumvent the domestic jurisdiction problem by a requirement of transnational racial connection between the intervenor and the victims:

In the treatment of its own citizens a state enjoys the largest freedom. Its conduct in that respect may be cruel and may visibly shock the sensibilities of the outside world. Nevertheless, the law of nations does not, by reason thereof, stamp it as illegal and of a character to justify interference. . . . It is conceivable, however, that the tyrannical conduct of a state towards its own subjects might directly affect a numerous class of subjects of another state, who were connected by blood with the victims of ill-treatment. If the injury thus sustained were of periodic recurrence and felt by large numbers of the population of the outside state, the latter would doubtless assert the right to intervene. In so doing it would find justification for its action on grounds closely analogous to those of self-defense..$^{72}$

In the period separating the first World War from the creation of the U.N. Charter, the same dichotomy runs through the doctrine, with scholars such as Fauchille, ${ }^{73}$ Stowell, ${ }^{74}$ Mandelstam, ${ }^{75}$ Seferiades, ${ }^{76}$ Le Fur, ${ }^{77}$ and Mosler $^{78}$ asserting that the

71. T. Lawrence, The Principles of International Law 129 (4th ed. 1910). Compare authorities in notes 46-47 supra and accompanying text.

72. Hyde, Intervention in Theory and Practice, 6 ILL. L. REv. 1, 6 (191112). Compare notes $204 \mathrm{ff}$. infra and accompanying text See also the Indian justification for intervening in East Pakistan, in Nanda, Self-Determination, supra note 1 at $334 \&$ n.94 and Nanda, Critique, supra note 1 , at 65 \& n.95.

73. See 1 P. Fauchile, Tratte de Droit International Public 570 (8th ed. 1922).

74. See Stowell, supra note 10 , at 52 .

75. See Mandelstam, supra note 67. See also A. Mandelstam, La Societe des Nations et les Puissances Devant le Probleme Armenien 1-32 \& 307 ff. (1926).

76. See Séfériadès, Principes Généraux du Droit International de la Paix (Hague Academy of International Law), 34 RecuerL DES Cours 381, 389 (1930).

77. See Lefur, L'INTERvention pour Cause D'humanite (1935), cited in Aronéanu, supra note 7, at 129. 
theory of humanitarian intervention has been assimilated by customary international law, while others such as Roxburgh, ${ }^{79}$ Higgins, ${ }^{80}$ Winfield, ${ }^{81}$ Potter, ${ }^{82}$ Strupp, ${ }^{83}$ Trolliet, $^{84}$ and Accioly ${ }^{85}$ ex-

78. See Mosler, supra note 34 , at 63 .

79. Roxburgh approximates Hodges' position (note 70 supra) in his statement that:

But whether there is really a rule of the Law of Nations which admits such interventions may well be doubted. Yet, on the other hand, it cannot be denied that public opinion and the attitude of the Powers are in favour of such interventions, and it may perhaps be said that in time the Law of Nations will recognize the rule that interventions in the interest of humanity are admissible.

1 L. Oppenheim, International Law 229 (3d ed. R. Roxburgh 1920) [hereinafter cited as OPPENHEIM].

80. Higgins adopts the Lawrence approach (note 71 supra and accompanying text), at least for unilateral humanitarian intervention in this statement that:

Interventions, whether armed or diplomatic, undertaken either for the reason or upon the pretexts of cruelty, or oppression, or the horrors of a civil war, or whatever the reason put forward ... would have .. . to justify themselves, when not authorized by the whole body of civilized states accustomed to act together for common purposes, as measures which, being confessedly illegal in themselves, could only be excused in rare and extreme cases in consideration of the unquestionable extraordinary character of the facts causing them, and of the evident purity of the motives and conduct of the intervening state.

W. Hall, A Treatise on International LaW 344 (8th ed. P. Higgins 1924) [hereinafter cited as HALL].

81. Winfield classifies humanity among the "alleged grounds of justification [of intervention] as to which international practice is uncertain." Winfield, The Grounds of Intervention in International Law, 5 BRIT. Y.B. INT'L L. 149, 161 (1924). He concludes: "But whether it is legal . . . must in the present state of practice be regarded as an unsolved point." Id., at 162.

82. Potter follows Oppenheim's 3d ed. (see note 79 supra) and Winfield (see note 81 supra), in their doubts as to the integration in customary international law of the doctrine of humanitarian intervention, primarily due to insufficient State practice:

Il ne semble pas que, dans la pratique internationale, ce droit ait jamais fait l'objet d'une reconnaissance indiscutable. ILes cas oị l'on s'en est prévalu sont trop peu nombreux, les divergences dans les thèses gouvernementales trop marquées-l'Etat qui subit l'intervention nie toujours l'existence de ce droit $\longrightarrow$ et la question dans son ensemble encore trop débattue, pour qu'on puisse affirmer que le droit dont il s'agit s'est établi d'une manière positive.

Potter, L'Intervention en Droit International Moderne (Hague Academy of International Law), 32 ReCUEIL DES CoURS 611, 653 (1930).

83. Strupp unambiguously rejects any lawful humanitarian intervention:

[P]artout où le droit des gens, valable entre l'Etat intervenant et celui contre lequel l'intervention est dirigée, n'accorde pas un droit spécial, l'intervention est illicite. Elle l'est aussi là où il $\mathrm{y}$ a intervention collective ... de même que là où l'humanité exige impérieusement ce que l'on a dénomme 'intervention d'humanité. Le droit des gens ne connait ni celle-ci, ni d'autres.

Strupp, Les Règles Générales du Droit de la Paix (Hague Academy of International Law), 47 ReCueIL des Cours 263, 517 (1934).

84. See Trolliet, Essai sur L'INTERVEntion en Droit INTERnational Public 66-70 \& 78 (1940).

85. See AcCIOLY, supra note 43 , at $282-83$. 
pressed doubts as to whether this incorporation had actually taken place.

Nevertheless in 1946, shortly after the United Nations had become a reality, Sir Hartley Shawcross felt entitled to declare at the Nüremberg Trials that:

[T]he right of humanitarian intervention, in the name of the Rights of Man trampled upon by the State in a manner offensive to the feeling of Humanity, has been recognized long ago as an integral part of the Law of Nations. ${ }^{86}$

\section{B. The Question of Norms: When is Humanitarian}

\section{Intervention Permissible?}

Caught up in the theoretical debate on the preliminary principle question of whether international law recognized a right of humanitarian intervention in general, the 19th and preCharter 20th century scholars devoted little attention to the study of the conditions under which such interventions, if at all permissible, could lawfully take place. The majority focused on the philosophical or politico-ideological foundations of their basic position and generally failed to supplement their initial choice with a comprehensive set of norms for decision-making or appraisal of actual cases.

Some loosely articulated criteria-examples of which include a widely shared preference for collective forms of action, ${ }^{87}$ insis-

86. H. Shawcross, Expose Introductif au Proces de Nuremberg, cited in Aronéanu, supra note 7, at 127 (emphasis added).

87. Amos indicated that:

It is in the highest degree desirable that the element of private interest should be entirely removed,-an object which can best be secured, in respect of such cases as these, by habits of combined policy among as great a number of States as possible.

Amos, supra note 65, at 159. Accord RIVIER, supra note 65, at 233:

Dies [nämlich Intervention zu Gunsten der Humanität] ist aber kein Fall berechtiger Intervention eines einzelnen Staates. Vielmehr lässt sich in solchen Fallen nur eine Kollektivintervention der Staaten, welche die Völkergemeinde bilden, rechtfertigen.

Compare, FIORE, supra note 62, at 522-23:

Ce qu'il importe de bien établir, c'est que, comme le motif légitime supposé d'intervention dériverait du devoir qui incombe à l'association des Etats d'observer et de faire respecter le droit international, un Etat ne pourrait pas être seul juge, et justifier ensuite l'intervention en alléguant qu'il existait une atteinte réelle au droit des gens. La société des Etats devrait seule avoir ce droit, et l'on doit considérer par conséquent comme une chose bien certaine, que l'unique garantie solide et exempte de danger serait la garantie collective des Etats qui vivent en société de fait. Toutefois, rien ne s'opposerait à ce que, lorsque les Etats associés auraient reconnu dans certains faits le caractère d'attentats au droit des gens, et employé d'abord tous les moyens pour rétablir l'ordre, l'un ou 
tence on disinterestedness of the intervenor, ${ }^{88}$ or restriction of the scope of applicability of the doctrine to certain situations only-civilized versus non-civilized nations, ${ }^{89}$ assistance to justified rebellion against tyranny, ${ }^{90}$ extreme atrocities, ${ }^{91}$ deprivation of certain specified, more fundamental human rights ${ }^{92}$-have been proferred. However, no integrated list of criteria of legality

l'autre d'entre eux ne put être délégué pour exécuter le mandat de punir l'offense dans les limites préalablement établies sauf ensuite le droit pour les Etats associés de régulariser les conditions de fait qui pourraient résulter de l'intervention.

But see 1 P. Fiore, Nouveau Droit International Public 225 (PradierFodéré transl. 1868). See also HaLl, supra note 80, at 344; Hodges, supra note 70, at 91; OpPenHeIM, supra note 79, at 229; Arntz, supra note 59, at 675; Winfield, supra note 81 , at 162 . Contra, Stowell, supra note 10, at 63, n.1: "[C]ollective intervention is often too unwieldy and too tardy to serve as a practical method of procedure."

88. Amos stated that "so far as [humanitarian] intervention is concerned, it is, above all, desirable that the purity of the motives should be conspicuous. ..." Amos, supra note 65, at 159. See also HALL, supra note 80, at 344; Manning, supra note 9, at 96 \& 97. Contra, Stowell, supra note 10, at $63, \mathrm{n} .1$ :

Desirable as it may be that humanitarian intervention should be, whenever possible, both disinterested and collective, this cannot be made a condition for the justification of the action taken. ... States are not generally willing to incur the burdens of intervention, even on the appealing ground of humanity, unless they are also actuated by other and more selfish considerations. . . .

89. See note 52 supra and accompanying text. See also J. BlüNTSCHLI, Le Droit International Codifie, arts. 5 \& 280 (1870), cited in Rougier, supra note 3, at 505 and J. Lorimer, PrINCIPES DE DROIT INTERNATIONAL 69 (Nys transl. 1885).

90. See discussion in note 39 supra. See also CreASY, supra note 48, at 303 \& 305; HefFTer, supra note 42, at 109-10; MANNING, supra note 9, at 97; VATTEL, supra note 35 , at 23.

91. Stowell urged that:

Dour que !'interrention d'humanité ne serye pas de prétexte d̀ une immixtion dans les affaires intérieures d'Etats voisins, la pratique internationale l'interdit pour le motif général de conduite inhumaine, sauf dans les cas où le traitement inhumain des particuliers, sujets des Etats voisins, résulte d'abus répétés ou continus, constituant une dénégation de certains droits reconnus aux particuliers dans toute communauté civilisée.

Stowell, La Théorie et la Pratique de l'Intervention (Hague Academy of International Law), 40 ReCUEIL DES CouRs 91, 141 (1932). See also HALl, supra note 80, at 344; Hershey, Essentials of International Public Law and Organization 239 (1927); MANNing, supra note 9, at 97; WoOlsEy, supra note 57 , at $57 \& 73$.

92. Fauchille wrote that:

Quels actes peuvent justifier une intervention d'humanité? Ce sont les actes attentatoires aux droits de l'homme, c'est-à-dire aux droits qui lui appartiennent en tant qu'homme, avant même qu'il fasse partie d'une société politique. Or, ces droits se résument en deux idées essentielles: droit à la vie et droit à la liberté.

FAUCHILle, supra note 73, at 570. Compare LEFUR, supra note 77 , cited in Aronéanu, supra note 7, at 128-29. 
was presented until the publication of Rougier's La Théorie de l'Intervention d'Humanité. ${ }^{93}$

After an extensive critique of the traditional notions of absolute sovereignty and equality of States, particularly in connection with the resulting doctrine of nonintervention, ${ }^{94}$ Rougier sets out what he calls "the theory of the law of humanity and of functional power." 95 Proceeding within the framework of this basic postulate, ${ }^{96}$ he analyzes and rejects the legality of individual intervention $^{97}$ and eventually opts for collective intervention on various policy ${ }^{98}$ and legal grounds. ${ }^{99}$ Pointing out, however, that "in fact, the scholars only require collegiality so as to ensure, among the intervenors, the combination of two conditions: namely disinterestedness and the widest possible authority,"100 he concludes that it is "the disinterestedness and the authority of the intervening States, and not their number, which provide legitimacy to the intervention."101 Observing that, while these two basic require-

93. Rougier, supra note 3 , at 497-525. For an outline and a short analysis of Rougier's criteria, see GaNJI, supra note 4, at 9-11.

94. Rougier, supra note 3 , at $480-89$.

95. Id., at 489-97. For a theoretical exposition, see Pillet, Le Droit International Public, 1 Rev. Gen. Dr. INT'L PUbl. 1 (1894); Pillet, Les Droits Fondamentaux des Etats, 5 Rev. GeN. DR. INT'L PuBL. 66 \& 236 (1898) and 6 Rev. Gen. DR. INT'L Publ. 503 (1899).

96. Rougier summarizes:

Cette théorie affirme l'existence d'une règle de droit générale s'imposant aux gouvernants comme aux gouvernés, supérieure au droit national et international qui n'en sont que des expressions particulières. Elle place sous la protection de cette règle les prérogatives essentielles de l'individu, ce qu'on appelle les droits de l'homme. Elle considère le pouvoir des gouvernants comme la contre-partie d'une fonction qu'ils ont à remplir, et conclut que le gouvernement qui manque à ses fonctions, partiellement dèchu de son pouvoir, poet subir le contrôle d'un Etat étranger.

Rougier, supra note 3, at 489.

97. Id., at 498-99.

98. Rougier enumerates the practical advantages of collective action as greater material and moral power, avoidance of conflict between intervenors acting independently without coordination, and increased impartiality due to the probable presence within the intervening collectivity of non-directly interested States. He argues that the inherent slowness of collective action could conveniently be remedied by delegation of the interventionary power to a single State. Id., at 499-501.

99. Rougier summarizes his legal analysis as follows:

Le droit d'agir contre une gouvernement inhumain appartient proprement à la Société des nations, gardienne du droit humain, que les actes tyranniques lèsent dans ses prérogatives essentielles; les puissances intervenantes sont ses représentants. Or la Société des nations ne peut être représentée que par une collégialité d'Etats.

Id. at 501 .

100. Id., at 502 .

101. Id. 
ments are generally fulfilled in the case of collective action, and that this is not necessarily controlling, ${ }^{102}$ Rougier formulates his own theory: "the system of disinterested and authorized intervention." 103

Acknowledging the de facto inequality of States, even within the same "civilization," and refusing to ascribe to the traditional principle of equality the character of a fundamental right of every State, he claims that: "the law can only acknowledge the natural hierarchy of power, moral authority or civilization that occurs between nations,"104 and that "protection of the collective interests requires the existence of rulers and ruled."105 Considering the actual distribution of power in the world, he concludes that certain States - the United States in the Americas, as recognized by the Monroe doctrine, and the "concert des grandes puissances" in Europe, as ascertained by almost a century of State practice ${ }^{106}$ _ "take control of the direction of general affairs and possess over the others . . . a legitimate authority."107 Insofar as their actions appear to be disinterested in that they tend to "ensure respect for the general rule of law and not to pursue the realization of an individual advantage," 108 this special authority, he submits, will allow them, individually in the case of the United States and collectively in the case of the European Major Powers, to intervene lawfully in their capacity of trustees and defenders of the law of humanity whenever the latter is seriously violated in another State.

Turning finally to substantive requirements of legality, Rougier lists the following three criteria:

1. that the event which ... motivates [intervention] be an action of the public authorities, and not merely of private individuals;

2. that this action constitute a violation of the law of humanity, and not merely a violation of national positive law; 3. that the intervention fulfill certain [circumstantial] requirements. ${ }^{109}$

102. Id.

103. Id.

104. Id., at 504 .

105. Id.

106. Id., at 507.

107. Id., at 506-07.

108. Id., at 502 .

109. Id., at 512 . 
Regarding the first ${ }^{110}$ of these criteria, he specifies:

The fault [of the] government can consist either of a positive action, or of an abstention. In the former case, the tyrannical measures are carried out or ordered by the very agencies of the State, with whom sovereign power rests, or by agents of the public service. ... In the latter case, the abuses are committed by private individuals, but they are tolerated by the government whereas it had the duty and the capability of preventing them. ${ }^{111}$

Regarding the second condition, ${ }^{112}$ he makes a distinction between the droits de l'homme- "which he possesses in his capacity as man even before his membership of a political society, and which he would continue to possess if he ceased to be a member [of such a society] ..."113 and the droits $d u$ citoyen-"which the individual possesses as a result of his membership of a political society ... "114 Only the former could, if violated, provide a sufficient ground for intervention ${ }^{115}$ since

[h]uman solidarity ... requires protection of the human physical, moral and social personality, but does not demand that an individual be allowed to exercise, in his particular society, certain given activities or benefit from certain social advantages; determination of these advantages is within the purview of the rules of national solidarity. ${ }^{116}$

Analyzing what rights, specifically, are to be considered droits de lhomme as opposed to droits du citoyen, and, as such, are in principle susceptible of lawful protection by foreign intervention, he concludes that only the right to life, ${ }^{117}$ the right to free-

110. See generally id., at 512-15.

111. Id., at 513 (emphasis added). Compare, discussion, note 248 infra.

112. See generally Rougier, supra note 3, at 512-23.

113. L. Duguit, Manuel de Droit Constitutionel 483 (1907), cited in Rougier, supra note 3 , at 516 .

114. Id.

115. Rougier noted that: "Seule la violation de ces droits essentiels serait une juste cause d'intervention." Rougier, supra note 3, at 517.

116. Id., at 516 (emphasis added).

117. Regarding this right, Rougier states: "Tout homme a droit au respect de sa vie, de son intégrité physique et à la libre disposition de son individu." Id., at 517. He furthermore considers the obligations of the State in this respect to be active as well as passive: "Il ne suffit même point que les gouvernements respectent la vie de l'individu; ils la doivent encore protéger." Id. He concludes:

Cette protection est une des fonctions primordiales qui s'imposent à toutes les sociétés politiques et dont le mauvais accomplissement peut justifier une intervention étrangère. L'application de cette idée la plus universellement admise en doctrine vise le cas où le Souverain fait massacrer ou laisse massacrer ses sujets.

1d. Compare notes $237 \mathrm{ff}$. infra and accompanying text. 
dom $^{118}$ and the right to legality ${ }^{119}$ can be included in the first category.

Finally, regarding his third criterion, ${ }^{120}$ he acknowledges that considerations of opportunity should, and in practice usually will, play an important role in the decision of a State with respect to whether to intervene. As factors particularly relevant for this process, he mentions "the extent of the scandal,"121 "a pressing appeal from the victims," 122 "the very constitution of the guilty state," 123 and "certain favorable conditions relating to the political

118. As to the substance of this right, Rougier observes: "La qualité d'être humain suppose la liberté physique et morale . . .." Rougier, supra note 3, at 518 . As to the latter, he specifies:

La liberté morale, à la différence de la liberté physique, ne peut jamais être enlevée à l'individu. . . . Le gouvernement le plus tyrannique peut seulement interdire les manifestations extérieures de cette liberté. . . . De telles mesures peuvent être contraires aux droits du citoyen, notamment au droit d'égalité, mais on ne saurait y voir des atteintes au droit humain, aussi longtemps du moins qu'elles ne s'accompagnent pas de persécutions violentes et d'attentats contre la vie et la liberté des individus.

Id., at 519 .

119. Rougier defines this right as:

[L]e droit pour tout individu d'être protégé dans son activité par un certain ordre légal, d'échapper au pur arbitraire de ses gouvernants, et de n'être frappé dans sa vie et dans ses biens que conformément à la loi, par une autorité juridictionelle régulière suivant des formes établies.

Id., at 521. He justifies the inclusion of this right among the droits humains by asserting that:

[L]'homme es un être social ne pouvant vivre isolément et . . . l'existence d'une société quelconque suppose l'establissment d'un ordre légal .... Le droit humain veut que tout regroupement d'hommes soit régi par une règle de droit.

Id. But he immediately qualifies this statement by adding:

Quant au choix et à la détermination de cette règle, c'est l'affaire de chaque société particulière. .... Si donc l'individu a un droit théorique à la légalité, l'établissement de cette légalité est une question d'ordre national. La droit de chaque homme se confond ici avec le droit du citoyen.

Id. He nevertheless argues that intervention for the protection of that right could lawfully take place "ou bien lorsque les institutions légales d'un Etat apparaissent inhumaines, ou bien lorsqu'un Etat viole les formes légales qu'il a édicté [sic] lui-même. . . ." Id., at 522. But he concludes, particularly in view of of the principle of opportunity: "[I]l semble que . . . le droit à la légalité doive rester un droit purement théorique. . . ." Id., at 523 .

120. See generally id., at 523-25.

121. Id., at 524. Rougier explains this requirement by specifying that intervention should be resorted to only:

[D]ans des cas exceptionellement graves, soit que la vie d'une population entière se trouve menacée, soit que les actes barbares se répètent habituellement, soit que leur caractère horrible choque plus violemment la conscience universelle.

Id. Compare notes 239 ff. infra and accompanying text.

122. Rougier, supra note 3 , at 524 .

123. Id. Rougier articulates this point by adding that States should refrain 
balance, the economic rivalries, the financial interests . . . [of the] intervenors ..."124

\section{Conclusion as to the Customary LaW}

Regarding the incorporation of the doctrine of humanitarian intervention as an established principle in customary international law, it has been demonstrated in the preceding analysis that, while historically there has never been unanimity on this point, there has, nevertheless, been some consistency since the latter part of the 19th century. As Lauterpacht points out there has been:

a substantial body of opinion and practice in support of the view that there are limits to [the] discretion [of states in the treatment of their own nationals] and that when a State renders itself guilty of cruelties against and persecutions of its nationals in such a way as to deny their fundamental human rights and to shock the conscience of mankind, intervention in the interest of humanity is legally permissible. ${ }^{125}$

Furthermore, it seems that a correct interpretation of the pre-Charter precedents corroborates neither Ganji's ${ }^{126}$ nor Potter's conclusions. ${ }^{127}$ Doubts may indeed be cast as to the sincerity of the humanitarian motivation of some of these cases. Examples of these include the unilateral large-scale military operations carried out by Russia against the Porte in 1877-1878 and the Macedonian war of 1912-1913. In spite of the formal treaty rights of a clearly questionable nature usually invoked by the intervening States, it seems irrefutable that their major underlying concern and true justification was the condition of the non-Moslem populations in the Ottoman Empire.

It is conceded that the precedents are not particularly num-

from intervening

[D]'autant plus que [l'Etat coupable] possède une organisation politique plus parfaite garantissant plus efficacement les libertés des citoyens contre l'arbitraire gouvememental. Aussi bien, dans un Etat semblable, les violations d'humanité seront rares et exceptionelles, liées à quelque convulsion politique profonde, et disparaitront d'elles-mêmes sans qu'il soit besoin d'une action internationale; celle-ci aurait plus de chances d'aggraver le mal que de le guérir.

1d. Compare authority cited in note 244 infra.

124. Rougier, supra note 3 , at 525.

125. OPPENHEIM, supra note 4, at 312. See also H. LAUTERPACHT, InTERNATIONAL LAW aND Human Rights $120 \mathrm{ff}$. (1950) [hereinafter cited as LAUTERPACHT].

126. "[T] practice of humanitarian intervention is limited to cases based on conventions." GANJI, supra note 4, at 43.

127. See discussion in note 82 supra. 
erous, but the extent of State practice necessary to create a rule of customary international law is a debatable question. That they are actually so scarce should not come as a surprise. As Lauterpacht explains:

The disinclination to take the responsibility for an international conflagration likely to follow upon such intervention or the consideration of the interests of the persecuted likely to suffer rather than to benefit from intervention unless fully backed by force, have been to some extent responsible for the relative infrequency of humanitarian intervention. ${ }^{128}$

In addition, customary international law is not created by State practice only. The opinions of the leading scholars, especially in an essentially non-institutionalized structure such as that of international law, have a significant impact upon the development of the legal norms of the system, as was reaffirmed in article 38 (1) (d) of the Statute of the International Court of Justice. ${ }^{129}$

The continuous reference throughout the twentieth century to the theory of humanitarian intervention, in the doctrine and in State practice (as in the case of the 1964 Stanleyville airdrop $^{130}$ and in that of the initial stage of the intervention in the Dominican Republic in $1965^{131}$ ), and supplemented by its de facto

128. OPPENHEIM, supra note 4, at 313. Regarding the motives for the lack of real interest on the part of both foreign governments and public opinion for human rights violations abroad, see Bilder, Rethinking International Human Rights: Some Basic Questions, 1969 WIS. L. Rev. 171.

129. The Statute provides that:

The Court, whose function it is to decide in accordance with international law such disputes as are submitted to it, shall apply: ... subject to the provisions of Article 59, judicial decisions and the teachingss of the most quactified publicists of the various nations, as a sübsidiary means for the determination of the rules of law.

I.C.J STAT., art. 38, para. 1(d) (emphasis added).

130. See, e.g., Statement by President Johnson, reprinted in 51 U.S. DeP'T State Bull. 846 (1964). See generally De Schutter, Humanitarian Intervention: A United Nations Task, 3 CALIF. W. INT'L L. J. 21-22 (1972) [hereinafter cited as De Schutter]; Lillich, Self-Help, supra note 7, at $338 \mathrm{ff}$.; The Congo Crisis 1964: A Case Study in Humanitarian Intervention, 12 VA. J. INT'L L. 261 (1972) [hereinafter cited as Congo Crisis].

131. See, e.g., Statement by President Johnson, reprinted in 53 U.S. DeP'T State Bull. 20 (1965). See generally Thomas \& Thomas, supra note 7; Bogen, The Law of Humanitarian Intervention: United States Policy in Cuba (1898) and in the Dominican Republic, 7 HARV. INT'L L. J. 296 (1965) [hereinafter cited as Bogen]; Bohan, The Dominican Case: Unilateral Intervention, 60 AM. J. INT'L L. 809 (1966); Fenwick, International Law, the O.A.S. and the Dominican Crisis, 19 Naval War College Rev. 18 (1966) [hereinafter cited as Fenwick, International Law]; Fenwick, The Dominican Republic: Intervention or Collective Self-Defense?, 60 AM. J. INT'L L. 64 (1966) [hereinafter cited as Fenwick, 
utilization in the Bangladesh crisis seem indeed to undercut the Thomases' contention that:

[Since u]nder the theory that to protest to a government would be to intervene in the internal political systems which recognize terror as a legitimate method of government, the democracies failed (prior to the advent of World War II) to protest the Nazi persecutions in Germany, the Franco persecutions in Spain and the Russian persecutions in Russia and satellite countries ... ., humanitarian intervention in the 20 th century . . . retains but little vigor. ${ }^{132}$

The cases referred to constitute flagrant examples of failure to invoke the doctrine in situations where it was genuinely demanded. ${ }^{133}$ That this provides sufficient ground for the conclusion that the doctrine of humanitarian intervention has fallen in disuse and consequently lost any relevance or validity in present times, is a much more questionable contention. It does not seem that international law requires constant, faultless utilization to avoid automatic abolition of a customary rule; many rarely used institutions of customary international law would otherwise have to be considered invalidated for lack of sufficiently frequent application. For example, it is doubtful whether hot pursuit has been used that often in recent times, and yet this right is unquestionably still accepted as a valid part of the general law of nations as attested by its restatement in article 23 of the 1958 Geneva Convention on the High Seas.

Turning finally to the normative problem, it appears that some widely accepted criteria of legality of humanitarian intervention can be distillated from the abundant literature on the subject. This can be done in spite of the overall vagueness and lack of structuration of the pronouncements by pre-Charter scholars:

Dominican Republic]; McLaren, The Dominican Crisis: An Inter-American Dilemma, 4 Can. Y.B. INT'L L. 178 (1966); Meeker, The Dominican Situation in the Perspective of International Law, 53 U.S. DeP'T StaTe Bull. 60 (1965); Nanda, The United States Action in the 1965 Dominican Crisis: Impact on World Order (Part 1), 43 DENVER L. J. 441 (1966).

132. A. Thomas \& A. Thomas, Non-intervention 373-74 (1965). Compare, BrownLIE, supra note 17 , at $340-41$ :

With the embarassing exception provided by Germany ['s invocation of the doctrine in defense of its intervention in Czechoslovakia], the institution has disappeared from modern state practice.

133. But see Reisman, supra note 4 , at 178 , referring to "[T] $]$ he Allied effort against the Axis in the Second World War" as an extreme example of "inclusive participation" in humanitarian intervention. 
(1) disinterestedness of the intervening Power(s), in the sense of a non-seeking of particular interests or individual advantages; $;^{134}$

(2) restriction of the applicability of the theory to extreme cases of atrocity and breakdown of order; ${ }^{135}$

(3) active participation or passive complicity or condonation of the violations by the sovereign; ; $^{138}$

(4) general predilection for collective action, ${ }^{137}$ by preference at the hands of the Major Powers, ${ }^{138}$ who have a particular responsibility ${ }^{139}$ for ensuring overall respect of minimal international standards of treatment of local populations.

As the foregoing study has shown, while divergences certainly existed as to the circumstances in which resort could be had to the institution of humanitarian intervention, as well as to the manner in which such operations were to be conducted, the principle itself was widely, if not unanimously, accepted as an integral part of customary international law. Indeed, "the doc-

134. Compare authorities in notes $249 \mathrm{ff}$. infra and accompanying text.

135. Compare authorities in notes $236 \mathrm{ff}$. infra and accompanying text.

136. Compare discussion in note 248 infra.

137. Compare authorities in notes $278 \mathrm{ff}$. infra and accompanying text.

138. As the Great Powers were then the only form of international "organization," this criterion is related to present day notions of primary responsibility of international organizations and the subsidiary character of humanitarian intervention. See authorities in notes $267 \mathrm{ff}$. infra and accompanying text.

139. This aspect is emphasized by Rougier who urges formal recognition by international law of this factual inequality. See text accompanying notes 94 \& 104 supra. This position is not astonishing. This author concurs with Perez-Vera in her statement that "aujourd'hui le principe de l'égalité souveraine de tous les Etats, malgré ses défaillances, s'oppose à un raisonnement de ce genre . ." Perez-Vera, La Protection d'Humanité en Droit International, [1969] Revue Belge de Droit International 401, 416 [hereinafter cited as Perez-Vera]. He would like to point out, however, that even today the principle of sovereign equality of States seems far from absolute in practice. The U.N. Charter declares that one of the purposes of the Organization is "to develop friendly relations among nations based on respect for the principle of equal rights . . . of peoples, . . . ." U.N. CharTer, art. 1, para. 2 (emphasis added). The Charter also declares that "The Organization is based on the principle of the sovereign equality of all its Members." Id., art. 2, para. 1 (emphasis added). The Charter nevertheless technically acknowledges the de facto inequality of its Member States by granting a veto power to the Permanent Members of the Security Council, thus recognizing that certain States are endowed with particular rights and responsibilities. Id., art. 27, para. 3. Further reference can be made to the problem of micro-States in general, and in particular, to recent proposals which have been made in the Organization of American States to restrict or prevent membership of a potentially large number of small Caribbean island-States on the brink of independence. 
trine of humanitarian intervention appears to have been so clearly established under customary international law that only its limits and not its existence is subject to debate."140

\section{Present Validity of the Customary Doctrine}

As many scholars have come to recognize in recent years, ${ }^{141}$ there is a need in the area of human rights to shift the field of study from the substantive to the procedural side; in other words, from defining human rights standards to creating machinery for their implementation and enforcement. ${ }^{142}$ As article 4. of the Proclamation of Teheran of May 13, 1968, noticed:

Since the adoption of the Universal Declaration of Human Rights the United Nations has made substantial progress in defining standards for the enjoyment and protection of human rights and fundamental freedoms ... but much remains to be done in regard to the implementation of those rights and freedoms. ${ }^{143}$

The numerous international human rights instruments which have been adopted by the U.N. General Assembly during the last two decades on the one hand, and the lack of any significant number of ratifications of most major conventions by the nations of the world ${ }^{144}$ on the other hand, seem to justify this conclusion and illustrate the problem of bridging the gap between mere theoretical lip-service dictated by political opportunism, and practical application of the acclaimed principles. The fact that the

140. INT'L L. Ass'N, The International Protection of Human Rights by General International Law, Interim Report of the Sub-Committee, International Committee on Human Rights 11 (The Hague 1970).

141. The International Law Association concluded that:

[T] he trend is now towards the establishment of international machinery and techniques for implementation .... that is to say ... some kind of supervision and control of the conduct of States in the observance of the standards now established.

INT'L L. Ass'N, Interim Report of the Committee on Human Rights, Report of the 52d Conference 754 (Helsinki 1966).

142. "The most difficult problem still confronting the framers of the United Nations' Human Rights Program is that of devising effective procedures for enforcement." McDougal \& Bebr, Human Rights in the United Nations, 58 AM. J. INT'L L. 603, 629 (1964).

143. International Conference on Human Rights, Final Act, U.N. Doc. A/CONF. 32/41, art. 4 (1968).

144. As of November 1971, for instance, only thirteen ratifications had been deposited for the Covenant on Civil and Political Rights and the Covenant on Economic, Social and Cultural Rights and four for the Optional Protocol on Civil and Political Rights. D. Harris, Cases and Materials on International LAw 531 n. $40 ; 539$ n.53; and 540 n.57 (1973). 
U.N. Human Rights Commission has finally taken the important step of deciding, in its rules of procedure, to take into consideration individual petitions concerning human rights violations, ${ }^{145}$ is but meager consolation. It is in those extreme cases where the most fundamental human rights are massively threatened, that the United Nations and the regional organizations, paralyzed by Major Power disagreements and the reluctance of the New States to accept any infringement upon the sacrosanct principles of sovereign independence and nonintervention ${ }^{146}$ in a setting lacking colonial or para-colonial ${ }^{147}$ aspects, ${ }^{148}$ have been unable or unwilling to take any significant measures. ${ }^{149}$ Biafra, Indonesia, Sudan, Burundi, Bangladesh, and, more recently, Uganda are but the most recent and bloody examples of the unfortunate passivity and ineffectiveness of the international organizations. ${ }^{\mathbf{1 5 0}}$

In view of this state of affairs, one might have good reason to question the wisdom ${ }^{151}$ of the now "classic" interpretation of

145. Sub-Commission on the Prevention of Discrimination and Protection of Minorities, Commission on Human Rights, Res. 1 (XXIV), U.N. Doc E/CN.4/ SUB.2 CRP.6, art. 2(a) (1971).

146. For statements by national representatives in the United Nations, see Fonteyne, Forcible Self-Help by States to Protect Human Rights: Recent Views from the United Nations, in HUMANITARIAN INTERVENTION AND THE UNITED Nations 197, at 205-06 \& n.39; 209-11 \& nn.53-58; 215-16 \& nn. 74-76 (R. Lillich ed. 1973) [hereinafter cited as Fonteyne].

147. The term "para-colonial" is used here to indicate the situation in Rhodesia or South Africa where black-white racism is a remnant of a colonial past, as opposed to "colonial" which indicates an overseas government situation, or "racial" which indicates a situation of racism lacking colonial origin.

148. For statements by national representatives in the United Nations, see Fonteyne, supra note 146, at 208 n.50.

149. "[T]he United Nations has not so far proved an effective instrument for remedying flagrant violations of elementary rights and freedoms." BRIERLY, supra note 7, at 295-96. See also Komarnicki, L'Intervention en Droit International Moderne, 60 Rev. GeN. DR. INT'L PUBL. 521, 566 (1956), observing after only a decade of U.N. activity, that:

[D]ans les conditions actuelles, les Nations Unies ne sont pas capables de sacquitter de leur tâche principale: contribuer au développement du droit international et à l'établissement de l'ordre international basée sur la justice, conformément aux buts et aux devoirs inscrits dans la Charte.

Compare, Remarks by Louis Henkin, in Biafra, Bengal, and Beyond: International Responsibility and Genocidal Conflict, 66 Proceedings AM. Soc'y INT'L L. 89, 96-97 (1972) [hereinafter cited as Remarks by Louis Henkin]:

[I]t is not possible in civil wars to isolate and act only upon genocide and other human rights violations. Indeed, usually the international community can not act at all, because of the national and international politics that dominate each civil war situation.

150. See, e.g., INT'L COMM'N OF JURISTs, supra note 1.

151. Lillich advocated that:

Surely to require a state to sit back and watch the slaughter of innocent people in order to avoid violating blanket prohibitions against the 
the Charter regulation of use of force as illustrated for instance by Mr. Gomez Robledo (Mexico) in the U.N. 6th Committee:

[U]nder article 2, paragraph 4, of the United Nations Charter it was clear that the use of force was permissible in only two cases: enforcement action ordered by the Security Council under article 42; and in conformity with article 51 individual or collective self-defence in the event of armed attack. $^{152}$

A departure from this strict constructionism of the Charter provisions relating to the use of force, and from the traditional domestic jurisdiction limitation, raises serious problems of Charter interpretation. To quote Professor Lillich:

[T]wo provisions make it "very doubtful" ... whether forcible self-help to protect human rights is still permissible under international law. In the first place, all states by Article 2(4) renounce "the threat or use of force against the territorial integrity or political independence of any state," subject of course to the self-defense provision contained in Article 51. Secondly, Article 2(7) prevents intervention by the United Nations "in matters which are essentially within the domestic jurisdiction of any state," except for the application of enforcement measures under Chapter VII. ${ }^{153}$

\section{A. The Domestic Jurisdiction Limitation and the Principle of Nonintervention ${ }^{154}$}

The principle of nonintervention, rather surprisingly in view of its wide acceptance ${ }^{155}$ at the time of the creation of the United Nations, is not explicitly provided for in the Charter regarding

use of force is to stress blackletter at the expense of far more fundamental values.

Lillich, Self-Help, supra note 7, at 344. Compare, J. Stone, Aggression AND WORLD ORDER 99 (1968) [hereinafter cited as STONE].

152. Mr. Gomez Robledo (Mexico), 18 U.N GAOR, 6th Comm., U.N. Doc. A/C.6/S.R.806, at 133, para. 12 (1963). For further statements in the United Nations, see Fonteyne, supra note 146, at 209-11 \& nn.53-58.

153. Lillich, Intervention, supra note 7, at 210-11.

154. See generally Ermacora, Human Rights and Domestic Jurisdiction (Hague Academy of International Law), 124 ReCuerl DES Cours 375 (1968) [hereinafter cited as Ermacora]; and Fawcett, Human Rights and Domestic Jurisdiction, in The International Protection of Human Rights 286 (E. Luard ed. 1967).

155. See, e.g., BRIERLY, supra note 7, at 402: "[C]ertain principles were fairly clear in customary law. Intervention, being a violation of another state's independence, was recognized to be in principle contrary to international law. .... 
inter-State relations. ${ }^{156}$ While article $2(4)$ specifically prohibits the threat or use of force between States, ${ }^{157}$ article 2(7) explicitly covers the relations between the United Nations and its Members only. ${ }^{158}$ This precludes the Organization from intervening in matters essentially within the jurisdiction of any State with the important exception of actions in respect to threats to the peace, breaches of the peace, and acts of aggression. ${ }^{159}$ However, this does not affect inter-State relations.

Notwithstanding some sporadic affirmations to the contrary, ${ }^{160}$ it seems that the explicit references in articles 1(2) and 2(1) of the Charter ${ }^{161}$ and the subsequent interpretation given to the nonintervention principle by a nearly unanimous doctrine and by the United Nations itself, justify the contention that the basic obligation of nonintervention in the domestic affairs of a State is equally, ${ }^{162}$ if not more, ${ }^{163}$ applicable on the level of interState relations.

156. Despite wide recognition as an integral part of customary international law, the principle of nonintervention was affected by vagueness and confusion. Lillich, Self-Help, supra note 7, at 330 \& n.31. As Brierly observed: "The law of intervention ... . was also sometimes obscured under the cloak of a political doctrine such as the Monroe doctrine. . . See BrIERLY, supra note 7, at 402. This, perhaps, provides a partial explanation for the indicated omission.

157. With the exception of article 51 situations, action in pursuance of a Chapter VII decision, and the now obviously irrelevant Article 107.

158. For statements by national representatives in the United Nations, see Fonteyne, supra note 146, at $204 \&$ n. 31.

159. U.N. CharTer, Ch. VII.

160. See, e.g., Mr. Schwebel (U.S.A.):

[I]n the United States' delegation's view article 2(7) of the Charter applied only to intervention by the United Nations, and . . intervention by one State in the affairs of another was illicit under the Charter only when it was accompanied by the threat or use of force. Articie 2(7) was the only provision in the Charter which made express reference to non-intervention, and the scope of State intervention was defined only in Article 2(4).

19 U.N. GAOR, Spec. Comm. on Fr. Rel., U.N. Doc. A/A.C.119/S.R.32, at 25 (1964). For further statements in the United Nations, see Fonteyne, supra note 146, at 204-05 \& n.33.

161. But see discussion and authorities at note 139 supra.

162. See, e.g., Mr. Colombo (Argentina):

The Charter of the United Nations prohibited the Organization from intervening in matters which are essentially within the domestic jurisdiction of any State. The same principle must be laid down in explicit terms in regard to relations between the States themselves.

19 U.N. GAOR, Spec. Comm. on Fr. Rel., U.N. Doc. A/A C.119/S.R.28, at 7 (1964). For further statements in the United Nations, see Fonteyne, supra note 146 , at $205 \&$ n.37.

163. The Representative from Cyprus stated that: "A very clear distinction should . . . be drawn between the concept of absolute sovereignty of States in relation to each other and that of the limited sovereignty of States in relation 
Today the whole range of activities relating to human rights, both in and outside the United Nations, as exemplified by the large number of declarations and conventions ${ }^{104}$ which have in recent years been adopted on the subject, ${ }^{165}$ indicate that the scope of domestic jurisdiction is dwindling. Further examples include the almost daily involvement of various U.N. agencies and organs with actual human rights problems; ${ }^{186}$ the repeated refusal by the General Assembly and the Security Council to accept article 2(7) of the Charter as preventing consideration by the United Nations of serious cases of human rights violations, ${ }^{167}$ particularly in a colonial or para-colonial context; ${ }^{108}$ and, the

to the United Nations." Mr. Rossides (Cyprus), 18 U.N. GAOR, 6th Comm., U.N. Doc. A/C.6/S.R.822, at 230, para. 9 (1963). Consequently, the nonintervention principle, as applicable to States, "had a much wider scope." Mr. El-Erian (United Arab Republic), U.N. Doc. A/C.6/S.R.811, at 164, para. 26 (1963). For further statements in the United Nations, see Fonteyne, supra note 146 , at $205 \& \mathrm{nn} .35-36$.

164. See generally Basic Documents on Human Rights (I. Brownlie ed. 1971).

165. A large number of those conventions have failed to obtain a sufficient number of ratifications to come into force. This does not basically alter the conclusion that the whole area of human rights is presently the subject of, at least theoretical permanent international attention.

166. See generally J. Carey, U.N. Protection of Civil and Political Rights (1970) [hereinafter cited as CAREY]; Ermacora, supra note 154; Higgins, Compliance with United Nations Decisions on Peace and Security and Human Rights Questions, in The EFfectiveness of InTERnational Decisions 34 (S. Schwebel ed. 1971).

167. Consideration of such cases was addressed by the Representative from Cyprus:

Since the adoption of the Charter, the general tendency had been ... to extend the possibilities of intervention by the United Nations. Thus article 2, paragraph 7 , of the Charter had repeatedly been interpreted by the General Assembly as allowing the United Nations to intervene in the internal affairs of a State in case of a flagrant violation of human rights or of the provisions of the Charter.

Mr. Rossides (Cyprus), 18 U.N. GAOR, 6th Comm., U.N. Doc. A/C.6/S.R.822, at 230, para. 10 (1963). Compare the lack of action by the United Nations in, for instance, the cases of human rights violations in Bulgaria, Hungary, Rumania, Tibet, Greece, and Haiti. See generally M. RAJAN, UNITED Nations AND DoMESTIC JURISDICTION 341 ff. (1958) [hereinafter cited as RAJAN]; Ermacora, supra note 154, at $415 \mathrm{ff}$. For statements by national representatives in the United Nations, see Fonteyne, supra note 146, at 206-09 \& nn.40-49 \& 5152.

168. See, e.g., Mr. Nachabe (Syria):

[A] state should not, under cover of the principle of non-intervention in domestic matters, commit acts contrary to the peremptory rules of international law, such as those which outlawed the discredited practices of colonial domination and attacks on human rights.

20 U.N. GAOR, 6th Comm., U.N. Doc. A/C.6/S.R.884, at 265, para. 52 (1965). For further statements in the United Nations, see Fonteyne, supra note 146 , at 207-08, nn. 46-48 \& 50 . 
world-wide concern of the public opinion with extreme cases such as Biafra, Southern Africa, Rhodesia or Bangladesh. ${ }^{169}$ These developments seem to substantiate Professor Ermacora's conclusion that:

[T] he right to self-determination and the protection of human rights in matters of discrimination as far as "gross violations" or "consistent patterns of violations" are concerned are no longer essentially within the domestic jurisdiction of States. . . ${ }^{170}$

Domestic jurisdiction is "an essentially relative question; it depends upon the development of international relations."171 In view of the variable character of the concept, ${ }^{172}$ it appears that the universal attention devoted to the way in which people are treated in their own country, and the practice of the United Nations in this field, must clearly be interpreted as indicating that human rights have finally been removed from the exclusive jurisdiction of States and lifted up into the realm of international concern. ${ }^{173}$ As a consequence, human rights have been placed outside the reach of the article 2(7) intervention ban, even in cases not amounting to a threat to the peace. ${ }^{174}$ This is true so

169. See generally P. JessuP, A Modern LaW of Nations 91 (1949) [hereinafter cited as JeSSUP]; LAUTERPACHT, supra note 125, at 177 ff.; OPPENHEIM, supra note 4, at 313; Thомаs \& THомas, supra note 132, at 376; Lillich, SelfHelp, supra note 7, at 338; McDougal \& Bebr, supra note 142, at 612. Compare the treatment of this question in connection with the U.N. mandatory economic sanctions against Rhodesia in McDougal \& Reisman, Rhodesia and the United Nations: The Lawfulness of International Concern, 63 AM. J. INT'L L. 1, $14 \mathrm{nn}$. (1969) [hereinafter cited as McDougal \& Reisman]. See also Howell, A Matter of International Concern, 63 AM. J. INT'L L. 771 (1969). Contra, Acheson, The Arrogance of International Lawyers, 2 INT'L LAwYER 591 (1968) [hereinafter cited as Acheson]. Compare, REDSLOB, supra note 7, at 250.

170. Ermacora, supra note 154 , at 436. For allegations to the contrary made on several occasions by South Africa in the United Nations, see CareY, supra note 166 , at $104 \mathrm{ff}$.

171. Tunis-Morocco Nationality Decrees Case, [1923] P.C.I.J., ser. B, No. 4, reprinted in 1 M. HUdSON, WORLD COURT REPORTS 143 (1943).

172. Rajan, supra note 167 , at 57 ff. Compare M. Moskowirz, Human RIGHTS AND WORLD ORDER 32 ff. (1958).

173. See Reisman, supra note 4, at $171 \mathrm{ff}$. Compare, The Question of Race Conflict in South Africa, Consideration by the General Assembly Between the 7th and 14th Sessions, 1952-1959, in SUMmary OF THE Practice OF THE UNITED

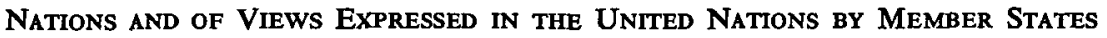
in Respect of four of the Principles of International law Concerning Friendly Relations and Co-operation among States in ACCordance with the Charter of the United Nations, Prepared by the Secretariat, 19 U.N. GAOR, Spec. Comm. on Fr. Rel., U.N. Doc. A/A.C.119/L.2, at 141, para. 288 (1964) [hereinafter cited as Summary]. Contra, id., at 141-42, para. 289.

174. See Reisman, supra note 4 , at 189 \& 190-91. Compare The Question 
far as measures by the United Nations are concerned, and probably regarding unilateral State action as well. ${ }^{175}$

\section{B. The Prohibition of the Threat of Use of Force}

As already indicated, what appears now to have become the "classic" view of the Charter prohibition of the threat or use of force in inter-State relations interprets article $2(4)^{176}$ in a broad way intended to encompass the entire range of possible situations. ${ }^{177}$

Relying primarily upon the intentions of the framers, the proponents of this approach stress the fact that the qualifying terms "against the territorial integrity or political independence of any State" ought not to be taken as restricting the absolute scope of the prohibition. Acknowledging that an "unqualified" interpretation of article 2(4) in fact constitutes a twist of the plain meaning of the text, Professor Giraud notices that:

This [restrictive] interpretation has not been retained. The

of Race Conflict in South Africa, Consideration by the General Assembly Between the 15th and 17th Sessions, 1960-1962, in Summary, supra note 173, at 146, para 298; The Question of Race Conflict in South Africa, Consideration by the Security Council in 1963 and by the General Assembly During the 18th Session, 1963, in Summary, supra note 173, at 149, para. 301.

175. See generally $R$. Higgins, The Development of International Law Through the Political Organs of the United Nations 118-30 (1963). Compare, Wright, Domestic Jurisdiction as a Limit on National and Supra-National Action, 56 Nw. U.L. Rev. 11 (1961). The conclusion which the present article reaches at this point does not mean that armed unilateral intervention for humanitarian purposes is permissible under the U.N. Charter, for there still remains the hurdle of the article 2(4) prohibition of use of force. This author contends only, at this stage, that, unless the position is taken that the nonintervention principle is stricter for States and should be distinguished from the article 2(7) limitation on U.N. jurisdiction, the preceding analysis justifies acceptance of less extreme forms of coercive unilateral action in situations of gross and persistent violation of the most fundamental human rights. This conclusion stands as long as one sticks to the "classic" interpretation of the term "force" in article 2(4), namely armed force, an approach suggested, among other things, by the Charter itself where it expressly lists, among the purposes of the Organization, the intention " $[t] 0$ ensure ... that armed force shall not be used, save in the common interest. ..." U.N. Charter, Preamble (emphasis added). Compare Brierly, supta note 7 , at $415-16$, concluding that "it is clear that article $2(4)$ does not preclude a state from taking unilaterally econom:c or other [measures] not involving the use of armed force." Arriving at a similar conclusion on the nonintervention point, but unwilling to go any further, the Thomases state:

The general international law right of an individual nation or a group of nations to intervene for humanitarian purposes remains unchanged, except that this intervention may no longer be taken by means involving the use or threat of force.

THomas \& THomas, supra note 132 , at 384. 
reason for it is that this interpretation does not correspond at all to the intentions of the drafters of the Charter. At the San Francisco Conference, that portion of the sentence referring to "the territorial integrity or the political independence" was added to the text merely to satisfy the small Powers who wished to see the guarantee of article 10 of the Pact of the League of Nations restated in the Charter, and not to restrict the scope of the prohibition of recourse to force. ${ }^{178}$

Similarly, regarding the final part of paragraph 4, Professor Wehberg points out:

The terms of the prohibition "in any other manner incompatible with the purposes of the United Nations," should not be interpreted as implying any other authorized use of force. ... One can ... refer [in this connection] to the statements of the American representative [at] the debates [of Committee I/1 of the San Francisco Conference], emphasizing that ... the sentence "or in any other manner" was intended to guarantee "that there would be no loopholes ...."179

Looking at the article 2(4) prohibition within the framework of the Charter as a whole, Sir Humphrey Waldock concludes:

[A]rticle 2(4) prohibits entirely any threat or use of force between independent States except in individual or collective self-defense under article 51 or in execution of collective measures under the Charter for maintaining or restoring peace. ${ }^{180}$

This interpretation, which can properly be considered the generally accepted one in the United Nations itself, ${ }^{181}$ views the Charter as a closed structure of self-sufficient norms, completely

176. The Charter provides that:

All Members shall refrain in their international relations from the threat or use of force against the territorial integrity or political independence of any state, or in any other manner inconsistent with the Purposes of the United Nations.

U.N. CharTER, art. 2, para. 4.

177. See note 152 supra and accompanying text.

178. Giraud, L'Interdiction du Recours d̀ la Force-La Théorie et la Pratique des Nations Unies, 67 Rev. GeN. DR. INT'L PUBL. 501, 512-13 (1963). See also Brownlie, The Use of Force in Self-Defence, 37 BRIT. Y.B. InT'L L. 183, 235 (1961).

179. Wehberg, L'Interdiction du Recours d la Force (Hague Academy of International Law), 78 RecueIL DEs CouRs 7, 70 (1951).

180. Waldock, supra note 7 , at 493 .

181. See note 152 supra and accompanying text. 
divorced from the pre-existing body of rules under customary international law. This would ensure as a system of conflict-management in which articles 2(4) and 51 are inversely correlative and intended to cover the whole spectrum of possibilities. ${ }^{182}$

When supported by the contention that "if nations had wished to exclude humanitarian intervention from these prohibitions . . . they would have done so explicitly," ${ }^{183}$ this approach leads necessarily to the general conclusion that

The landing of armed forces of one state in another state is a "breach of the peace" or "threat to the peace" even though under traditional international law it is a lawful act. It is a measure of forcible self-help, legalized by international law because there has been no international organization competent to act in an emergency. The organizational defect has now been at least partially remedied through the adoption of the Charter and a modernized law of nations should insist that the collective measures envisaged by art. 1 of the Charter shall supplant the individual measures approved by traditional international law . . . . ${ }^{184}$

182. Compare, Röling, supra note 7 , at 177 , who supports humanitarian intervention as an additional exception, not explicitly provided for in the Charter, on the basis that "a legal rule without exceptions does not exist." He further comments that: "It is impossible to formulate rules of law in such a way that the most extreme and rare situations would be dealt with. An endeavour to achieve such a rule would amount to perfectionism." Id.

183. Thomas \& Thomas, supra note 7 , at 22 , referring to the Latin-American doctrine. Mencer noted that:

L'institution de la soi-disant intervention humanitaire ne constitue, dans

le droit international contemporain, aucune institution autonome, telle pour laquelle la donnent certains auteurs dans une certaine mesure. Elle ne constitue pas une exception de l'applicabilité générale et absolu [sic] de l'interdiction d'intervention. L'article 2, alinea 4, de la Charte interdit aux Etats la menace ou l'emploi de la force, et il se conçoit que l'intervention pour des raisons humanitaires n'est pas citée en tant qu'exception de cette interdiction générale. Elle ne figure pas non plus, en qualité d'exception, à l'article 2 , alinéa 7 .

Mencer, supra note 16, at 314-15. This contention raises the fundamental question as to whether the Charter must be construed as abolishing all pre-existing norms of customary international law which it does not specifically and explicitly save, or has left unaffected those traditional rules which are not necessarily in contradiction with its own provisions and purposes. This author tends to favor the latter position for a variety of reasons, including the widely shared principle of interpretation in domestic law, which could be applied here by analogy, in that the technique of implicit repeal of pre-existing laws must be restrictively interpreted, and applied only when contradiction with the new rules is unavoidable. Compare, Nanda, supra note 131, at 478. See also Report of the 6th Committee, 18 U.N. GAOR, Annexes, Vol. III, Agenda Item 71, U.N. Doc. A/5671, at 34, para. 61 (1963); Samuels, in Humanitarian InTERVENTION AND THE UNited Nations 43 (R. Lillich ed. 1973).

184. JESSUP, supra note 169, at 169-70. 
Applying this approach specifically to humanitarian intervention, Dr. Brownlie logically concludes:

[I]t is extremely doubtful if this form of intervention has survived the express condemnations of intervention which have occurred in recent times ${ }^{[185]}$ or the general prohibition of resort to force to be found in the U.N. Charter. ${ }^{180}$

Faced with the problem of the de facto inability and political unwillingness both of the United Nations ${ }^{187}$ and of the regional organizations, ${ }^{188}$ to take any significant action, other than

185. It seems, however, that there has never been a clear and unambiguous condemnation by the United Nations of a specific instance of humanitarian intervention as such. In connection with the 1964 Stanleyville airdrop, for example, Nanda concludes: "[T]he Council Resolution after the Stanleyville debate [does] not prohibit such action, nor . . . specifically permit it." Nanda, supra note 131, at 477-78. Similarly, Bastid sums up her evaluation of the same Security Council debates as follows:

Sous réserve du problème difficile de l'appréciation des conditions dans un cas concret il semble bien qu'au cours de ce débat le prinçipe même de l'intervention d'humanité n'ait pas été contesté. De ce point de vue la position des représentants des Etats d'Amérique latine, traditionellement attachés au principe de non-intervention doit être spécialement relevée. Le Délégué du Brésil a déclaré que l'action humanitaire pour sauver la vie d'ôtages était légitime quant à ses motifs et aux moyens employés. Tel a été aussi l'avis du représentant de la Bolivie ....

Bastid, Remarques sur l'Interdiction d'Intervention, in MELANGes OfFerTs A JURAJ ANDRASSY 13, 21 (1968). Compare, Statement by Mr. Bouattoura (Algeria), cited in id., at 20. See also R. FAlK, Legal Order in a Violent World 329-31 \& 334 (1968) [hereinafter cited as FaLK]; The Congo Crisis, supra note 130, at 269 ff. \& 273; De Schutter, supra note 130, at 23 \& n.10.

186. BRownLIE, supra note 17 , at 342 . Mencer rejects the usefulness of analyzing whether one could or should distinguish between permissible and impermissible interventions:

Il est . . . impossible de continuer utilement la recherche scientifique de cette questions [sic] au moyen d'une méthode qui, bien qu'elle se soit acclimatée est évidemment dójà dópassée et vieillie à présent, savoir [sic] au moyen de la méthode de distinction d'interventions ... selon la forme (par exemple .... intervention individuelle ou collective, économique, financaire, commerciale, idéologique, humanitaire ou autres [sic] .... Sous l'angle méthodolog:que et, d'autant plus, sous l'aspect théorique ... non seulement la forme, mais aussi le motif de l'intervention est sans importance .... A présent, la théorie artificielle des soi-disants motifs légitimes est ensontenable [sic] ... alle [sic] n'a aucune justification scientifique ... Aucune de ces "justifications" n'affaiblit pas [sic] les conséquences de la violation de la souveraineté de l'Etat contre lequel l'intervention a été dirigée . . .

Mencer, supra note 16, at 304-05. He concludes: "La science progressiste de droit international s'oppose . . . à toutes les doctrines de l'intervention légitime." Id., at 307.

187. See text accompanying note 150 supra.

188. Referring to the Organization of African Unity, Thapa observes:

The African Organization, a loose association of African States, lacks among its members a coherence of aims and principles, so that it has proven of little use in the handling of regional problems. Particularly, inhuman treatment, unless at the hands of white rulers, does not come among its list of immediate concerns; which casts doubts as to whether 
humanitarian relief measures, ${ }^{189}$ to remedy even extreme situations of human rights deprivations other than those involving apartheid or racial discrimination in a colonial or para-colonial context, ${ }^{190}$ an increasing number of scholars have been seeking legal and extra-legal arguments to justify unilateral humanitarian operations. ${ }^{101}$

The approach which they have taken towards this problem is not uniform and as a result two major strands can be distinguished. They can conveniently be described as the "double level" and the "legal" approach.

The proponents of the "double level" approach ${ }^{192}$ accept the "classic" view on the Charter prohibition of unilateral use of force as a necessary corrollary to the attainment of what they see as the United Nations' primary goal. That is, maintenance of in-

any collective action of the African organization for such purposes would be forthcoming if the necessity arose.

Thapa, Humanitarian Intervention, 75 (1968) (unpublished thesis in McGill University Law School Library) [hereinafter cited as Thapa].

189. On this level as well, the United Nations has encountered serious difficulties in performing its task. See, e.g., on relief operations in Biafra: Remarks by Beverley May Carl, in Biafra, Bengal, and Beyond: International Responsibility and Genocidal Conflict, 66 ProceEdings AM. Soc'y INT'L L. 89, $103 \mathrm{ff}$. (1972); Address by Senator Edward M. Kennedy, id., at 90 . See generally Gottlieb, International Assistance to Civilian Populations in Armed Conflicts, 4 N.Y.U.J. INT'L L. \& PoI. 403 (1971) [hereinafter cited as Gottlieb].

190. Even in a para-colonial situation such as Rhodesia, where the United Nations has taken certain measures, their significance in terms of effectiveness in attaining their objective is, to say the least, questionable. See, e.g., Statement of Senator Harry F. Byrd Jr., in Hearings on S.1404, U.N. Sanctions Against Rhodesia-Chrome, Before the Senate Committee on Foreign Relations, 92d Cong., 1st Sess. (1971). See generally Sanctions against South Africa (R. Segal ed. 1964).

191. Jenks advocates that:

[T] he world community must recognize the need ... for external intervention in cases not covered by the right of self-defense as so defined [in Article 51 of the Charter] in which a world interest or the conscience of mankind is involved. The world community cannot tolerate acts of savagery on the ground that its civilised members have renounced the threat and use of force in their international relations.

JENKS, A NEW World of LAW? 30 (1969) [hereinafter cited as JeNKs].

192. See generally the debates of the Charlottesville Conference on Humanitarian Intervention and the United Nations (March 11-12, 1972), reprinted in Humanitarian INTERVENTION aNd THE UNited Nations 3-135 (R. Lillich ed. 1973). See also Brownlie, Thoughts on Kind-Hearted Gunmen, id., at 13948 [hereinafter cited as Brownlie, Gunmen]; Brownlie, Humanitarian Intervention, in LAW ANd Civil WAR IN THE MODERN WORLd (J. Moore ed. 1973). For a rebuttal, see generally Lillich, Humanitarian Intervention: $A$ Reply to Dr. Brownlie and a Plea for Constructive Alternatives, LAW AND CIVIL WAR IN THE MODERN WORLD (J. Moore ed. 1973). 
ternational peace and security through elimination of all forceful interactions between States that are not comprised among the legal exceptions expressly mentioned in the Charter: individual and collective self-defense and action in pursuance of a Chapter VII decision. They feel compelled, in view of the already demonstrated inability or unwillingness of the international organizations to cope with such dramatic situations as Biafra or Bangladesh, to acknowledge that the absolute interpretation of the Charter prohibition on use of force by States is an unworkable and unacceptable restriction upon last resort unilateral action in case of extreme violation of the most fundamental human rights. Nevertheless, they are not prepared to depart from their allegiance to their basic force-minimalization position and to consider an eventually revived customary doctrine of humanitarian intervention which would fully legalize this kind of action as an additional exception not explicitly provided for in the Charter. On the other hand, they point to the lack of formal condemnation or criticism on principle in the United Nations and in other international fora in such cases as the Stanleyville operation or the Indian intervention in Bangladesh. From this they conclude that, in circumstances of extreme gravity, the world community, by its lack of adverse reaction, in practice condones conduct which, although a formal breach of positive legal norms, appears "acceptable" because of higher motives of a moral, political, humanitarian, or other nature. ${ }^{193}$ This lack of express condemnation in specific cases, they submit, would in fact confer to such actions the character of some kind of second-tier or sub-legality. ${ }^{194}$

Insofar as this approach purports to give an accurate description of the lex lata and its application, ${ }^{195}$ not much can be raised

193. See Franck, in Humanitarian INTERVENTION AND THE UNITED Nations 64 (R. Lillich ed. 1973); Frey-Wouters, id., at 107-08; Friedmann, id., at 114; Wright, The Legality of Intervention Under the United Nations Charter, 51 PRoCEEDINGS AM. SOc'y INT'L L. 77, 81 (1957); Remarks by Louis Henkin, supra note 149 , at 96 .

194. See Lillich, in Humanitarian INTERvention and the United Nations 61-62 \& 118 (R. Lillich ed. 1973); Falk, id., at 68-69. Compare, on the subject of reprisals which raises similar, if not stronger, problems of justification under the U.N Charter: Falk, The Beirut Raid and the International Law of Retaliation, 63 AM. J. INT'L L. 415, 430 n.39 (1969); Bowett, Reprisals Involving Recourse to Armed Force, 66 AM. J. INT'L L. 1, 10-11 \& 26 (1972).

195. See, e.g., on the absence of formal condemnation of India in the Bangladesh context: Nanda, in Humanitarian INTERvention aNd THE UNITED NATIONs 99 (R. Lillich ed. 1973). Among the numerous draft proposals submitted between 1962 and 1970 by Member States of the United Nations on the question 
against it. When, however, its proponents condone it, so to say de lege ferenda, as the most suitable system for attaining a fair balance between the seemingly contradictory goals of protection of human rights in extreme cases and maintenance of a peaceful world order, ${ }^{196}$ this author cannot agree.

The main arguments which have been advanced in support of this approach comprise: ${ }^{197}$ fear of abusive invocation of a fully legalized doctrine of humanitarian intervention; practical restraints upon the conduct of States due to the necessity of, at least "technical" breach of the law; clarity and simplicity of the general rule of total prohibition of armed intervention, coupled with the fear that recognition of an exception for humanitarian motives might "erode the psychological constraints of the use of force for other purposes;" 198 and, concordance with the present

of further articulating Charter norms on the prohibition of force, both in the 6th Committee and in the Special Committee on Principles of International Law Concerning Friendly Relations and Co-operation Among States, none explicitly provided for any exceptions not specifically envisaged by the Charter. Only one such draft, submitted by the United Kingdom, specified in its written commentary that its paragraph 5, embodying the two Charter exceptions (article 51 and Chapter VII) in a broad interpretation, was intended to "set . . . out in a non exhaustive manner the principal circumstances in which the use of force is lawful." Commentary, United Kingdom Proposal, 19 U.N. GAOR, Sp. Comm. on Fr. Rel., U.N. Doc. A/A.C.119/L.8, at 4 (1964) (emphasis added).

196. Compare, Prof. Moore's distinction between the respective intellectual tasks of description of what the law is and recommendation as to what it ought to be. Moore, in Humanitarian INTERVEntion AND THE UNITEd Nations 12021 (R. Lillich ed. 1973).

197. See generally Farer, Humanitarian Intervention-The View from Charlottseville, in HUMANITARIAN INTERVENTION AND THE UNITED NATIONS 149, 152 \& $155-57$ (R. Lillich ed. 1973) [hereinafter cited as Farer, Humanitarian Intervention]; Brownlie, Gunmen, supra note 192, at 147-48; Franck, in HuMaNTTARIaN INTERVENTION AND THE UNITED NATIONS 14, 64 \& 89 (R. Lillich ed. 1973); Falk, id., at 33; Frey-Wouters, id., at 107-08; FALK, supra note 185, at 161; Gottlieb, supra note 189 , at $415 \& \mathrm{n} .48$.

198. Farer, Humanitarian Intervention, supra note 197, at 152. Another argument sometimes advanced is the likelihood of humanitarian intervention actually causing more harm than benefits to the people it is intended to assist. Franck, for instance, observes that:

[T]here is a strong indication that more people died in Bangladesh during the two or three weeks when the Indian Army was liberating the country than had been killed previously.

Franck, in Humanitarian INTERVENTION AND THE UNITED Nations 65 (R. Lillich ed. 1973). See also Farer, Humanitarian Intervention, supra note 197, at 152. Finally, it has been argued that a flat prohibition of humanitarian intervention might have the beneficial effect of inducing States to resort to (non-coercive) measures at an earlier stage so as to prevent the situation from deteriorating and reaching such proportions that armed intervention becomes the only effective remedy left. Franck, in Humanitarian INTERvention aNd tHe UNITEd Nations 104-05 (R. Lillich ed. 1973). Contra, Lillich, in id., at 109. 
state of the law.

So far as the fear of abuse is concerned, this author must confess that he is unable to see how a "double level" theory, recognizing the permissibility of certain illegalities, would in any respect reduce the opportunities for abusive utilization. It seems likely that a clearly stated rule, restricting by a set of precise criteria the lawfulness of humanitarian intervention to certain well-defind, specific situations, would provide a far stronger incentive for a State to refrain from intervening in a situation or in a manner falling short of the requirements set forth for its legality. This would be much more effective than would a system in which the prospective intervenor knows that, regardless of his motives, he breaches the law, but can hope that the world community will remain silent as a result of apathy or political division, and thus implicitly condone his intervention, however selfish its purposes may have been. ${ }^{199}$

Such a situation would certainly enhance neither clarity nor predictability. An absolute prohibition undermined by creeping exceptions puritanically called "acceptable breaches" seems hardly more straightforward in application than a rule which openly recognizes some limited and strictly defined exceptions, by permitting appraisal and eventual characterization of the conduct of an intervenor as unlawful.

In addition, "[i]t would indeed be wrong to unnecessarily brand conduct unlawful which is morally justified." 200 This could

199. Significant is Prof. Franck's rationale for opposing legal recognition of humanitarian intervention:

[A]s a lawyer I would prefer to advise politicians contemplating such intervention to look to political rather than legal justifications and mitigation. Political leaders who are contemplating unilateral military intervention should not be encouraged to believe that international law is firmly on their side. It is not. At best, it is unclear. They could still take their chances on a cogent political justification being accepted as genuine by the international community.

Franck in Humanttarian Intervention and the United Nations 64 (R. Lillich ed. 1973) (Emphasis added).

200. Bogen, supra note 131, at 303. This author does not wish to go as far as Bogen who, referring to the absence of any action by the world community prior to World War II regarding the persecutions of Jews in Nazi Germany, contends that law-abiding nations could be dissuaded from intervening for humanitarian reasons in situations genuinely requiring it, by the absence of an applicable legal exception to the general rule of prohibition of the use of force, and accordingly criticizes the "absolute" interpretation of article 2(4) on that ground. Id. Compare, Farer, Humanitarian Intervention, supra note 197, at 160 and Franck, in HumantTarian INTERVENTION IN THE UNITED Nations 89 (R. Lillich ed. 1973). 
only encourage States to run the risk, break the law, invoke some vague, plausible higher motive, and hope that the world community will fail to censor their conduct. In the long run such a situation must inevitably lead to an increasing authority defiation of international law in general, and of the Charter in particular. ${ }^{201}$ If States can "acceptably" break the law for humanitarian reasons, why should it not be equally tolerable to violate it for other, perhaps morally less commendable motives as well?

Thus it seems that the only real advantage of the "double level" approach is its complete correspondence with the present state of the law, integrating at the same time the strict theoretical prohibition of unilateral use of force for any reason not amounting to self-defense, and the practice of non-condemnation of at least some types of "technical" violations of this norm. In view of the various disadvantages this theory entails, it might be advisable in assessing what the law ought to be, to frame the recommended rule in such a way as to attach the label of lawfulness to what is deemed acceptable. ${ }^{202}$

In view of the highly improbable character of a Charter revision expressly integrating unilateral use of force for humanitarian purposes as an additional exception to the general prohibition of use of force by States, those scholars who want the legality of past and future instances of humanitarian operations recognized, have tried to find bases in the Charter, as it presently stands, to support their contention.

The Thomases, in rather cautious terms, conclude that:

In spite of a recognition of a right of humanitarian intervention by customary international law, strict principles of modern multilateral treaty law may have completely abolished the right . . . 203

Nevertheless, in connection with article 51 of the Charter, they contend that:

201. See Prof. Falk's description of this approach as "advocating civil disobedience on an international level." Falk, in Humanitarian InTERvention AND THE UNITE NATIONS 108 (R. Lillich ed. 1973). See also the euthanasia and marijuana laws parallels referred to by Prof. Lillich in Humanitarian INTERVENTION AND THE UNITED NATIONS 62, 117 \& 118 (R. Lillich ed. 1973) and Dr. Brownlie, in Brownlie, Gunmen, supra note 192, at 146.

202. Compare, Farer, Humanitarian Intervention, supra note 197, at 160; Baxter, in Humanitarian INTERVENTION aNd THE UNITED Nations 54 (R. Lillich ed. 1973); Almond, id., at 133 \& 134.

203. Thомаs \& Thomas, supra note 7 , at 20 (emphasis added). 
A plea can be made that where it is legal to intervene to protect one's own nationals, it is an extension of this legality to protect the nationals of others. The so-called principle of nationality is not inflexible . . . ${ }^{204}$

They seemingly endorse the often invoked argument that selfhelp to protect one's own nationals can be deemed included in the "inherent" right of self-defense retained by article $51,{ }^{205}$ and go on to extend this permissibility through an "ancillarity-like" rationale to cover situations in which the nationality link is missing. ${ }^{206}$

Attractive though this reasoning might be, particularly in those cases where a State, intervening to rescue some of its own nationals, avails itself of the opportunity to save other foreigners as well, ${ }^{207}$ this author has serious reservations regarding this approach. For one thing, it is by no means certain that even protection of nationals can properly be taken to fall within the purview of self-defense as defined in article 51.208 Secondly, from a pol-

204. Id.

205. See, e.g., BowetT, supra note 7, at 91-105; D. Greig, InTernational LAW 673 (1970) [hereinafter cited as GREIG]; STONE, supra note 151, at 94-97; A. Thomas \& A. Thomas, The Organization of American States 162 (1963); Fenwick, International Law, supra note 131, at 27; Fenwick, Dominican Republic, supra note 131, at 64. See also Report of the 6th Comm., 18 U.N. GAOR, Annexes, Agenda Item 71, U.N. Doc. A/5671, at 34, para. 61 (1963). This rationale has also been relied upon by the United Kingdom in support of its intervention in the 1956 Suez crisis. See, e.g., Statement of Prime Minister Eden in the British House of Commons, cited in Fawcett, Intervention in International Law (Hague Academy of International Law), 103 RecueIL DES CoURS 347, 400 (1961).

206. Compare, Responsibility of States for Damage Done in their Territories to the Person or Property of Foreigners, Report of the League of Nations Cormmittee of Experts for the Progressive Codification of International Law, SubCommitee on State Responsibility, 20 AM. J. INT'L L. 177, 182 (Spec. Supp. 1926), cited in THOMAs \& Thomas, supra note 7, at 20.

207. Particularly when the State whose nationals have been rescued by the intervenor supports or condones the latter's actions, very little can be asserted against the legality of this type of "simultaneous rescue" operation, provided the intervention of the acting State for the protection of its own nationals and is deemed legal in the first place. The operation might then be considered to have been carried out on behalf of all the States involved, and therefore within the scope of collective self-defense. Compare, statements cited in note 211 infra.

208. "The extent to which the right to self-defense includes a right of protection over nationals abroad ... has been, and in a lesser degree remains, the subject of acute controversy." JENKS, supra note 191, at 30 . See also BrownLIE, supra note 17, at $429 \mathrm{ff}$. The terms of article 51, taken literally, require (1) an armed attack (2) directed against the State. This seems to make it rather difficult to "equate protection of nationals abroad with the preservation of the state itself." Lillich, Self-Help, supra note 7, at 336 . On the other hand, the 
icy perspective, the inclusion of self-help to protect nationals abroad in the right of self-defense of the State itself, does raise some serious questions. To the extent that this broad view of self-defense emphasizes the functional character of the State ${ }^{209}$ as an institution whose goals and interests only acquire a real content through their relationship with the interests and security of its constituting elements, namely man, this author agrees. The real danger of equating self-help to protect individuals abroad with selfdefense of the State as a whole, however, lies in its potential to incite States to disregard any notion of proportionality and to resort to force as soon as even a very small group of their nationals is endangered. Likewise, where the size of the threatened group would genuinely justify drastic measures of protection, to use an amount of force unrelated to the extent of the actual hardship to be prevented. ${ }^{210}$ And thirdly, this rationale seems hardly applicable to those situations in which the violations reach the most dramatic proportions, namely where the victims are nationals of the State committing the violations. Foreign intervention will then by and large have to take place contrary to the wishers of that State's gov-

qualification of the term self-defense as an "inherent right" could be taken to indicate that article 51 merely restates the customary right to self-defense, which traditionally did include self-help in situations not amounting to an armed attack upon the State. This is illustrated by the now classic formulation of self-help by Webster in relation to the incident of the steamer Caroline in 1837: "[A] necessity of self-defense, instant, overwhelming, leaving no choice of means and no moment for deliberation." U.S. Secretary of State Webster, cited in Nanda, supra note 131, at 48 (emphasis added). Some support for a broader interpretation of article 51 beyond the plain meaning of its terms can also be found in the I.C.J.'s qualified acceptance of the legality of the initial measures taken by the United Kingdom in the Corfu Channel incident. Corfu Channel Case, [1949] I.C.J. 4, 30. Compare, McDougal, Authority to Use Force on the High Seas, 20 Naval WaR College Rev. 19, 28-29, cited in Lillich, Intervention, supra note 7 , at 217 n.58:

I'm ashamed to confess that at one time I lent my support to the suggestion that article $2(4)$ and the related articles did preclude the use of self-help less than self-defense. On reflection, I think that . . . article $2(4)$ and article 51 must be interpreted differently .... In the absence of collective machinery to protect against attack and deprivation, I would suggest that the principle of major purposes requires an interpretation which would honor self-help against prior unlawfulness.

See generally BrIERLY, supra note 7, at 416 ff.; L. Goodrich \& E. Hambro, Charter of the United Nations: Commentary and Documents $229 \mathrm{nn}$. (1949); H. Kelsen, The Law of the Untred Nations 791 (1950); Stone, supra note 151, at 98 ff. For statements by national representatives in the United Nations, rejecting a broad interpretation of article 51, see Fonteyne, supra note 146 , at $217 \& \mathrm{nn} .79-81$.

209. Compare, notes 95-96 supra and accompanying text.

210. Compare, Lillich, Self-Help, supra note 7, at 337 \& n.77. 
ernment, thus eliminating any possibility of rational invocation of collective self-defense, however broadly one stretches the concept. $^{211}$ Unlike in a protection-of-nationals case, the absence of any transnational connection other than general international concern with human rights, excludes characterization of such cases as even minimally threatening, directly or indirectly, the intervening State's interests or security. Unless one transposes to the inter-State level the encouraging but somewhat artificial threat to the peace rationale utilized by the United Nations to justify mandatory sanctions against Rhodesia, ${ }^{212}$ it appears extremely difficult to vindicate resort to measures of self-help in this context.

The more commonly taken approach combines three main arguments: restrictive interpretation of the article 2(4) prohibition; balancing out of the Charter's major purposes; and limited invocation of the non-realization of the basic expectations of the Members of the United Nations when they renounced their right under customary international law to use force unilaterally. ${ }^{213}$

Article 2(4) of the Charter, it is argued, should be interpreted in accordance with its plain language, so as to prohibit the threat or use of force only when directed at the territorial integrity or political independence of a State. ${ }^{214}$ Taken in con-

211. Compare, statements by national representatives in the United Nations, justifying assistance to colonial peoples on the basis of an extended collective self-defense rationale, in Fonteyne, supra note 146, at 213-14, nn.67-69. See also id., at 214 n.70. See generally Payne, Sub-Saharan Africa: The Right of Intervention in the Name of Humanity, 2 GA. J. INT'L \& CoMP. L. 77 (1972).

212. The Security Council, in declaring the Rhodesian situation to constitute a threat to the peace, recognized that deprivations of human rights and of the right to self-determination on the internal level, could threaten international peace and security. These could trigger forceful reactions of neighboring or other States. See generally Fenwick, When Is There a Threat to the Peace?Rhodesia, 61 AM. J. INT'L L. 753 (1967); Franck, Policy Paper on the Legality of Mandatory Sanctions by the United Nations Against Rhodesia, CENTER FOR InT'L Studies, Pub. No. 1 (1968); McDougal \& Reisman, supra note 169; Robinowitz, U.N. Application of Selective Mandatory Sanctions Against Rhodesia: A Brief Legal and Political Analysis, 7 VA. J. INT'L L. 147 (1967). Contra, Acheson, supra note 169.

213. See Thомаs \& Thomas, supra note 7, at 16; Lillich, Self-Help, supra note 7, at 334 ff.; Lillich, Forcible Self-Help under International Law, 22 NAvaL War College Rev. 56 (1970) [hereinafter cited as Lillich, Forcible Self-Help]; Lillich, Intervention, supra note 7, at $210 \mathrm{ff}$.; McDougal \& Reisman, supra note 7; Perez-Vera, supra note 139; Reisman, supra note 4; Thapa, supra note 188. This author has attempted to integrate in one theory various arguments advanced by the above scholars. This does not mean, however, that each of them explicitly articulates the whole range of arguments in this article, or would necessarily agree with every contention made in the following exposition.

214. "A close reading of [article $2(4)$ ] will indicate that the prohibition 
nection with article 51, this would mean that these two provisions are not necessarily complementary, in that situations might arise in which armed force is utilized unilaterally neither against the political independence of territorial integrity of any State, nor in the exercise of the inherent right or individual or collective selfdefense. Specifically, "[s]ince a humanitarian intervention seeks neither a territorial change nor a challenge to the political independence of the State involved," 215 and particularly in view of the closing words of article 2(4) referring to the purposes of the Charter, this specific modality of the use of force is "not only not inconsistent with the purposes of the United Nations but is rather in conformity with the most fundamental peremptory norms of the Charter."216

This position does not overlook the various policy problems raised by this interpretation of article 2(4), one of the major ones being that this approach would necessitate a case by case appraisal of the alleged motivation and purposes of any action claimed to fall under the exception. This would not of course simplify the norm or its application in practice. ${ }^{217}$

is not against the use of coercion per se, but rather the use of force for specified unlawful purposes. ..." Reisman, supra note 4, at 177 . Compare, statements by national representatives in the United Nations, in Fonteyne, supra note 146 , at 214 \& n.71.

215. Reisman, supra note 4, at 177. See also Lillich, Self-Help, supra note 7, at 336; Lillich, supra note 213, at 63; Perez-Vera, supra note 139, at 415.

216. Reisman, supra note 4 , at 177 . He concludes: "[I]t is a distortion to argue that [humanitarian intervention] is precluded by article 2(4)." Id. See also Perez-Vera, supra note 139 , at 415 . Lillich argues that "[c]ertainly, if a construction of the Charter, namely article $2(4)$, will further human rights, it is a proper construction." Lillich, supra note 213, at 63. Compare, Claude, in Humanitarian INTERvention and THE UNITED NAtions 42 ( $R$. Lillich ed. 1973); statements by national representatives in the United Nations, in Fonteyne, supra note 146 , at 215 \& n.73. Contra, statements in the United Nations, id., at 215-16, nn. 74-76; JENKS, supra note 191, at 29; GreIG, supra note 205, at 668 . See also note 179 supra and accompanying text. The same apparent contradiction of purposes can be found in recent restatements of the nonintervention principle by the U.N. General Assembly, such as the Declaration on the Inadiaissibility of Intervention in the Domestic Affairs of States and the Protection of their Independence and Sovereignty, G.A. Res. 2131 (XX), 20 U.N. GAOR, Supp. 14, U.N. Doc. A/6014, at 11 (1965), and the Declaration on Principles of International Law Concerning Friendly Relations and Co-opertaion Among States, G.A. Res. 265 (XXV), 25 U.N. GAOR, Supp. 28, U.N. Doc. A/8028, at 121 (1970). See generally Note, A Proposed Resolution Providing for the Authorization of Intervention by the United Nations, a Regional Organization, or a Group of States in a State Committing Gross Violations of $\mathrm{Hu}$ man Rights, 13 VA. J. INT'L L. 340, 342 (1973) [hereinafter cited as Proposed Resolution].

217. For statements by national representatives in the United Nations, see 
From the standpoint of text interpretation as well, the argument can be criticized, for this approach takes the words "against the territorial integrity or political independence of any State" to refer to the motives and goals of the State resorting to force. Article 2(4), on the other hand, does not indicate that it relates to the intentions of the parties. ${ }^{218}$ In fact, even in those limited cases of rescue of foreigners, where it is possible for the intervenor to pull out very quickly without really affecting the internal authority structures of the State intervened in, armed intervention will still inevitably constitute a temporary violation de facto of the latter's territorial integrity and, to a certain extent, of its political independence, if carried out against its wishes. In most instances of humanitarian intervention on behalf of peoples deprived of their most fundamental human rights by or with the approval of their own government, the infringement upon the State's territorial integrity and political independence will be far more serious. Achievement of a lasting solution in such cases will usually require a change of government or even a secession, so that the foreign intervention will have had to fundamentally influence the domestic political process and organization of the State intervened in.

Considering article 2(4) in the broader perspective of the major purposes of the Charter, ${ }^{219}$ and specifically in view of the closing words of paragraph $4,,^{220}$ there is clearly a need for balancing the sometimes opposite goals of conflict-minimalization and protection of human rights. ${ }^{21}$ Espousing Professor Lillich's view

Fonteyne, supra note 146, at 209-11 \& nn.54-58. On the other hand, an appraisal of these and other subjective elements is already needed with the present "classic" approach towards the Charter prohibition of force. The validity of a ciaim that a certain conduct falis under the articie $5 \mathbf{i}$ exception of seif-defense cannot meaningfully be assessed by applying merely mechanical tests. See, e.g., Statement by Mr. Chaumont (France), 25 U.N. GAOR, Spec. Comm. on Aggression, U.N. Doc. A/A.C.134/S.R.57, at 36 (1970). However, the traditional Soviet "chronological" approach towards the determination of acts of aggression could be adopted. See, e.g., Draft U.S.S.R. Resolution, 9 U.N. GAOR, Annexes, U.N. Doc. A/C.6/L.332/Rev.1, at 6-7 (1954).

218. Jenks notes that:

The reference to 'territorial integrity or political independence' can be so construed as to introduce an element of ambiguity into the obligation [to refrain from the threat or use of force] but not reasonably so as to substitute a subjective test of intention for the objective test of the nature and effect of the action taken.

JENKS, supra note 191, at 28-29.

219. See U.N. Charter, Preamble, paras. $1 \&$ 2, and art. 1, paras. $1 \& 3$.

220. But see authorities in notes 179 and 216 supra.

221. Reisman, however, advocates that:

The preamble and critical first Article of the Charter, framed in the awful shadow of the atrocities of the war, left no doubt as to the inti- 
that "a prohibition of violence is not an absolute virtue"222 and that "it has to be weighed against other values as well," ${ }^{223}$ Professors McDougal and Reisman contend that:

The continuing authority of community expectations about the lawfulness of humanitarian intervention is greatly confirmed by all the contemporary developments associated with the United Nations. The repeated, insistent emphasis upon its underlying policies can only be regarded as strengthening, not weakening, the historic remedy. ${ }^{224}$

Referring in particular to articles $55^{225}$ and $56^{226}$ of the Charter, which they interpret as transforming the general commitment of U.N. Members to human rights into "an active obligation for joint and separate action, ${ }^{227}$ they submit that:

[T] he cumulative effect of the Charter in regard to the basic policies of the customary institution of humanitarian intervention is to create a coordinate responsibility for the active protection of human rights: members may act jointly with the Organization in what might be termed a new organized, explicitly conventional humanitarian intervention or singly or collectively in the customary or international common law humanitarian intervention. Any other interpretation would be suicidally destructive of the explicit major purposes for which the United Nations was established. ${ }^{228}$

And conclude that:

Insofar as it is precipitated by intense human rights deprivations and conforms to the general international legal regulations governing the use of force-economy, timeliness, commensurance, lawfulness of purpose, and so on-[humanitarian intervention] represents a vindication of interna-

mate nexus that the framers perceived to link international peace and security and the most fundamental human rights of all individuals. Reisman, supra note 4 , at 171 .

Compare authorities in note 292 infra and accompanying text.

222. Lillich, Forcible Self-Help, supra note 213, at 65.

223. Id.

224. McDougal \& Reisman, supra note 7, at 442 .

225. The Charter provides that: "[T]he United Nations shall promote ... universal respect for, and observance of, human rights and fundamental freedoms for all without distinction as to race, sex, language or religion." U.N. CHARTER, art. 55.

226. "All Members pledge themselves to take joint and separate action in cooperation with the Organization for the achievement of the purposes set forth in Article 55." U.N. Charter, art. 56 (Emphasis added).

227. McDougal \& Reisman, supra note 7, at 444.

228. Id. 
tional law . . . 229

Furthermore, since "[the] great expectations of the immediate postwar period have not materialized," 230 in that the machinery for collective security and enforcement envisaged by the States ratifying the Charter has in fact not been established, ${ }^{231}$ one might wonder whether a State would not be entitled to challenge the absolute validity of the Charter prohibition of force and fall back upon the traditional doctrine of humanitarian intervention in those exceptional cases of extreme human rights deprivations. ${ }^{232}$

As long as the necessity of strictly defining and limiting the circumstances in which States could rely upon this latitude is kept in mind, would it not be advisable to consider the present poten-

229. Reisman, supra note 4, at 177.

230. Lillich, Self-Help, supra note 7 , at 335 . These hopes have been cruelly deceived in that no article 43 agreements have been concluded, the Security Council is often paralyzed on important issues by the crippling and constant use of the veto, and the agenda of the General Assembly has been virtually monopolized by the "new" nations for discussion of colonial and para-colonial subjects. Compare, Baxter, in HumanitaRian INTERVEnTION AND THE UNITED Nations 5354 (R. Lillich ed. 1973); Lillich, id., at 61.

231. Arguably, the establishment of machinery for collective security and enforcement was so basic a condition for the Members of the United Nations in surrendering their right under customary international law to use force for a variety of reasons, that failure by the Organization to create this machinery would partially relieve the Member States of their obligation of restraint under the Charter. See, e.g., Statement of Mr. Shahi (Pakistan), 23 U.N. GAOR, 6th Comm., U.N. Doc. A/C.6/S.R.1080, at 9, para. 68 (1968). As Prof. Stone's views regarding the Charter prohibition of force indicate, an outright "contractlike" approach to the Charter could prove extremely hazardous in that this might totally undermine the conflict minimalization structure which, for the first time in history, has been established through the replacement of the ciiterion of "just war" by that of self-defense. See generally Stone, supra note 151. Compare, JENKS, supra note 191, at 30: "Injustice, subjectively determined, does not justify the threat or use of force to protect or enforce rights which the community has not yet evolved adequate means of securing." See also Henkin, Force, Intervention, and Neutrality in Contemporary International Law, 57 Proceedings AM. Soc'Y INT'L L. 147, 148-49 (1963).

232. In reference to this possibility, Thapa states that:

[A]n absolutist view, that the Charter has abolished the customary principle of humanitarian intervention, is not defensible-this principle continues to exist as an exception to all rules, whether set forth by customary or conventional international law, which bans forceful intervention for such purpose.

Thapa, supra note 188 , at 13 . Writing against the background in view of the Biafran crisis, and listing the various types of intervention permissible under the U.N. Charter, Adaramola concludes: "It seems that in extreme conditions humanitarian intervention will be justified." Adaramola, The Nigerian Crisis and Foreign Intervention: $A$ Focus on International Law, 4 NIGERIAN L.J. 76, 78 (1970). 
tials of the international organizations? Similarly, it seems reasonable to recognize legally, that in certain extreme situations, when neither the United Nations nor the competent regional organization can or wants to assume its responsibilities, a State may be temporarily relieved of its obligation of restraint under article $2(4)^{233}$ so as to provide a form of "substitute or functional enforcement of international human rights."234

\section{Criteria for Appraisal of Humanitarian Intervention}

Various scholars have, in recent times, formulated modernized criteria for appriasal of the legality of alleged cases of humanitarian intervention. ${ }^{235}$ While overlapping on a large nuniher of points, the proposed norms, nevertheless, show some significant variations. This author will attempt to reconcile and supplement them in three major groups: substantive, procedural, and preferential criteria.

\section{A. Substantive Criteria}

1. Characteristics of the Situation Warranting Humanitarian Intervention: limitation to ongoing or imminent large-scale deprivations of the most fundamental human rights. ${ }^{236}$

a) Fundamental character of the human rights involved: Without going as far as Professor Perez-Vera who considers only the right to life sufficiently essential to warrant a departure by a State from the principle of prohibition to force, ${ }^{237}$ this author believes that a balance must be struck between the amount of destruc-

233. As early as 1949 Jessup envisaged this possibility:

It would seem that the only possible argument against the substitution of collective measures under the Security Council for individual measures by a single state would be the inability of the international organi-

zation to act with the speed requisite to preserve life.

Jessup, supra note 169, at 169 . But see Brownlie, Gunmen, supra note 192, at $145-46$.

234. Reisman, supra note 4 , at 178.

235. See Lillich, Self-Help, supra note 7, at 347 ff.; Moore, The Control of Foreign Intervention in Internal Conflicts, 9 VA. J. INT'L L. 205, 263-64 (1969) [hereinafter cited as Moore]; Nanda, supra note 131, at 475; Perez-Vera, supra note 139, at 416 ff. See generally Reisman, supra note 4; Thapa, supra note 188. Compare discussion and authorities in notes $87 \mathrm{ff}$. supra and accompanying text.

236. Reisman generally refers to an "overriding necessity" for intervention. Reisman, supra note 4, at 193. Compare, De Schutter, supra note 130, at 28 . 29 , requiring a "breach . . . of a certain qualitative and quantitative gravity." See also Proposed Resolution, supra note 216, at 357-61.

237. Perez-Vera, supra note 139 , at 418. 
tion which almost inevitably will be caused by armed intervention, and the importance of the human rights sought to be protected. This weighing process tends to result in a restriction, in principle, of the permissibility of humanitarian intervention to those situations where there is a threat to, or deprivation of the most fundamental types of human rights, such as the right to life or the freedom from torture. ${ }^{238}$

b) Exceptionally large scale of the human rights deprivations: To the extent that unilateral resort to force for humanitarian motives is to be considered "an exceptional measure, available as a last resort to prevent irreparable injury,"239 armed intervention should only be permissible "when a substantial deprivation of human values" 240 is involved. While "[j]ust counting heads . . . is not sufficient for decision-making purposes," 241 the number of people affected by the human rights violations is not completely irrelevant. There ought to be a reverse correlation between the latter and the seriousness of the violated human rights: ${ }^{242}$ the larger the number of people involved, the more readily will a deprivation of a lesser fundamental human right provide sufficient justification for intervening.

Analyzing each specific case in a cost-benefit fashion, it would be necessary, "using the principles of relativity and proportionality as guidelines," ${ }^{243}$ to balance the destruction intervention would cause and the size of the group affected by the violations, as well as the fundamental character of the threatened human rights. Additionally, the degree of potential persistency of

238. Moore requires a threat "to fundamental human rights, particularly a threat of widespread loss of human life." Moore, supra note 235, at 264 (emphasis added). See also Moore, in Humanitarian INTERVENTION AND THE UNITED Nations 49 (R. Lillich ed. 1973); Lillich, Self-Help, supra note 7, at 348.

239. BoweTt, supra note 7, at 98 (emphasis added).

240. Lillich, Self-Help, supra note 7 , at 348 . Perez-Vera limits it to "des crimes spécialement révoltants, d'une cruauté extrème ... ou bien des massacres de nature à blesser la conscience de l'humanité." Perez-Vera, supra note 139 , at 418 . Thapa refers to "a substantial threat to a large number of persons. ..." Thapa, supra note 188, at 67. Reisman requires "a grave threat to minimum human rights." Reisman, supra note 4, at 187 . See also Moore, supra note 235, at 264.

241. Lillich, Self-Help, supra note 7, at 348.

242. " $[I] \mathrm{t}$ is necessary to examine the type as well as the extent of human rights deprivation ...."Id. See also Claydon, in Humanitaruan INTERvenTION AND THE UNited Nations 91-93 (R. Lillich ed. 1973).

243. Lillich, Self-Help, supra note 7, at 348. 
the situation and the chances of independent internal solution of the problem should be taken into consideration. ${ }^{244}$

c) Immediacy of the human rights violations: Being an extraordinary measure of last resort, humanitarian intervention would be justified only when "the substantial deprivation ... . has occurred or is threatened."245 However, a problem of perception and appraisal arises. While the seriousness of the situation can by and large be assessed once the deprivations are taking place, whether a threatened violation actually turns into physical violence must necessarily remain a matter for speculation. This is particularly applicable if this potential development is in fact prevented by a foreign intervention allegedly justified by this danger.

However, since:

[T] he main basis of humanitarian intervention is the protection of humanity, there cannot be a principle forcing the intervening party to wait until the destructive act has been committed. Such intervention being preventive rather than punitive, the existence of the imminent danger is sufficient. ...246

It would be illogical and inconsistent with the purpose of the intervention to require "a state ... [to] wait for an actual violation to occur before taking preventive action."247 The test must be one of reasonableness: a good faith determination by the prospective intervenor that human rights violations are in fact imminently threatening, on the brink of evolving into actual mass deprivation. ${ }^{248}$

244. This might constitute an exceedingly difficult criterion to apply due to its highly contingent and subjective character. Nevertheless, this author submits that even in an extreme case of violation of the most fundamental human rights of a large group of people (such as in the case of an organized policy of genocide carried out by the local authorites), foreign intervention of a forceful nature would probably not be warranted if there is a reasonable prospect that the deprivations will end in the immediate future as a result of internal political or other processes. The preservation of values to be achieved by intervention must be weighed against the extent of the disruption of internal structures and domestic processes which will necessarily result from the foreign action. In such a case, this author would certainly oppose anything beyond preservation measures merely intended to allow the domestic process of resolution of the crisis to operate without the hardship and cost in human values it might otherwise have been accompanied with.

245. Lillich, Self-Help, supra note 7, at 348. Compare, Moore's reference to "[a]n immediate and extensive threat. . . ." Moore, supra note 235, at 264 (emphasis added).

246. Thapa, supra note 188 , at 40 (emphasis added).

247. Lillich, Self-Help, supra note 7, at 348.

248. Compare, Proposed Resolution, supra note 216, at 361-62. Perez-Vera 
2. Characteristics Relating to the Motivation of the Intervening State: "relative" disinterestedness-As one writer observes:

The States are not generally responsive to the call of humanity at the risk of incurring blame for intervention, unless they are also motivated by other and more selfish considerations. ${ }^{249}$

Disinterest is indeed "a highly altruistic principle [and] as such ... practicable only for individuals but not to an entity like a state." 250 If an opportunity is to be maintained for States to intervene in human rights situations without breaking the law, it seems surely "naive," 251 to use Professor Lillich's terms, and unrealistic to require that "where the decision to intervene falls to a single state, it should be safeguarded by a requirement that the state be totally disinterested." 252 The presence, among the reasons of the intervenor, of some considerations of national interest should not be taken to necessarily "invalidate the resort to [force] if the overriding motive is the protection of human rights."253

further requires that the violation of human rights be "imputable à la puissance publique elle-même," and this "aussi bien par une action que par une omission." Perez-Vera, supra note 139, at 418. This author is compelled to disagree with this criterion, undoubtedly inspired by the traditional principles of State responsibility for injury to aliens, applied by analogy. It disregards the essentially remedial character of humanitarian intervention and introduces the notions of guilt regarding the State intervened in and of a right of punishment on the part of the intervening State. From a pragmatic point of view, it would seem to put an undue limitation on the protection of human rights by foreign intervention in situations where the deprivations are the result of, for instance, persistent public unrest which the local authorities are unable, not unwilling, to control, or of violence exerted by a portion of the population in rebellion against the de jure government. Compare, De Schutter, supra note 130, at 29. See also Farer, in HumanitaRian INTERVENTION AND THE UNITEd Nations 66 (R. Lillich ed. 1973), referring to a possible distinction "between the case where the threat [to human rights] is the consequence of governmental action and the case where it is the result of a breakdown in government."

249. Thapa, supra note 188, at 14-15. See also id., at 86-87. Compare, authorities in note 128 supra and accompanying text.

250. Thapa, supra note 188 , at 83 . Compare, Moore, in Humanitarian INTERVENTION AND THE. UNITED NATIONS, at 30 \& 70 (R. Lillich ed. 1973).

251. Lillich, Self-Help, supra note 7, at 350.

252. Bogen, supra note 131, at 311. See also Perez-Vera, supra note 139, at 416 .

253. Lillich, Self-Help, supra note 7, at 350 . Thapa rejejcts the current relevance of the requirement of absolute disinterestedness, as included in the traditional doctrine of humanitarian intervention, on the basis that this criterion has

[N]ot been able to play a convincing role. The [reason] mainly being that ... the U.N., as a proper agency (having assimilated ... [this 


\section{Characteristics of the Intervention Itself.}

a) No unnecessary force: ${ }^{254}$ This criterion is in fact an application of the general principles of necessity and proportionality, ${ }^{255}$ and has a double aspect. For one thing, the intervening State should not only utilize the modality of coercion required for the achievement of the humanitarian objectives it seeks to attain. ${ }^{258}$ If it then appears that recourse to armed force is unavoidable, the intervenor should "employ only the amount of troops reasonably necessary to accomplish the objective," ${ }^{257}$ so as to reduce to a minimum the infringement upon the territorial integrity and political independence of the State intervened in.

b) No unnecessary affectation of the authority structures of the State intervened in: Closely related to the requirement of disinterestedness of the intervenor, ${ }^{258}$ this criterion is again an application of the general principles referred to in the preceding paragraph. To the extent that it does not flatly prohibit any intentional impact upon the domestic political processes, it clearly

condition] in its constitution) of intervention for the sake of humanity, has proven, at present, to be incapable of intervening as efficiently as the States are able to.

Thapa, supra note 188, at 14. See also Proposed Resolution, supra note 216, at 365-66. Contra, Gottlieb, supra note 189, at 416, requiring that "[g]enuine humanitarian intervention . . . must be . . . kept free from political objectives."

254. See Lillich, Self-Help, supra note 7, at 349-50; Moore, supra note 235, at 264; Nanda, supra note 131, at 475; Perez-Vera, supra note 139, at 420-21; Reisman, supra note 4, at 177; Proposed Resolution, supra note 216, at 36768. See also Nanda, in Humanitarian INTERVENTION aNd the UNITEd Nations 78 (R. Lillich ed. 1973).

255. Nanda, supra note 131 , at 478 . Compare, Reisman, supra note 4 , at 193, requiring "compliance with the international law of the use of force."

256. Compare authorities in notes $264 \mathrm{ff}$. infra and accompanying text.

257. Lillich, Self-Help, supra note 7, at 349-50 (emphasis added). This criterion is particularly important, both for the appraisal a posteriori of the legality of an actual intervention and for purposes of decision-making. In determining whether to intervene for the protection of human rights in another State, governments should take into consideration the amount of force which the safe achievement of this objective is likely to require, and balance out the inevitable destruction this will cause against the value of the objective to be attained by it. Compare Moore, supra note 235 , at 264 , referring to "a proportional use of force which does not threaten greater destruction of values than the human rights at stake." On the different aspects of the proportionality principle in this context, see generally the exchange between Profs. Franck, Weston, Nanda and Cardozo (Moderator), in HumantTARIAN INTERVENTION AND THE UNited Nations 8-9 (R. Lillich ed. 1973). See also Moore, id., at 50; Farer, id., at 7.

258. See authorities in notes $249 \mathrm{ff}$. supra and accompanying text. Nanda, supra note 131 , at 475 , refers broadly to a "specific limited purpose." See also Nanda, in HumantTarian INTERvention aNd the UNITED Nations 78 (R. Lillich ed. 1973); Proposed Resolution, supra note 216, at 364-65. 
reflects the fundamental value-choice that human rights protection justifies at least some degree of interference with the political independence and sometimes even territorial integrity of the State intervened in. ${ }^{259}$ At the same time, it purports to limit the lawfulness of extensive alteration by the intervenor of the internal authority structures of that State, to those situations where overthrow of the government in power or even secession of a part of the population appears to be the only available means of putting an end to ongoing or threatened human rights violations of particular gravity. ${ }^{260}$

c) No unnecessary duration of the operation: Based on the same principles as the previous two criteria, the requirement of limited duration, ${ }^{261}$ should be considered a relative one ${ }^{262}$ in that removal of the intervening troops should be required only when the objectives of the operation have been achieved ${ }^{263}$ - provided they

259. The importance of this fundamental value choice is highlighted by the finding that "the most important abuses of human rights are those committed by governments, and often by governments acting within their own territorial domain." Falk, in Humanitarian INTERvention aNd tHe UNITEd Nations 27 (R. Lillich ed. 1973). In further support of this basic value choice, McDougal and Reisman invoke the reference in article $1(2)$ of the Charter to "[r]espect for the principle of equal rights and self-determination of peoples . . . (Emphasis added). This would be enhanced by necessarily authority-oriented humanitarian intervention. McDougal \& Reisman, supra note 7, at 442. But see Adamarola, supra note 232, at 80-81:

It must be pointed out that the principle of self-determination has been accepted by the United Nations as a lever of action for the liberation of subject and dependent peoples of the world, and not as an instrument for the dismemberment or desintegration of states.

260. See generally Farer, Humanitarian Intervention, supra note 197, at 15354; Franck \& Rodley, supra note 7, at 283. See also Proposed Resolution, supra note 216, at 367. Compare, Moore, who implicitly limiting the practical possibility of lawful humanitarian intervention to mere rescue operations of nationals of the intervening State, or eventually of third States, clarifies his requirement of "minimal effect on authority structures" as follows:

If the protection of human rights requires the overthrow of authority structures, it would seem best to require United Nations authorization as a prerequisite for action. To allow unilateral action in such cases would be to permit all manner of self-serving claims for the overthrow of authority structures.

Moore, supra note 235, at 264. But see Moore, in Humanitarian InTERVEnTION ANd the United Nations 50 (R. Lillich ed. 1973). Compare, Remarks by Louis Henkin, supra note 192, at 96.

261. Nanda, supra note 131, at 475. Compare, Perez-Vera, supra note 139 , at 420 .

262. Lillich concludes merely that "[t]he longer the troops remain in another country, the more their presence begins to look as [political] intervention." Lillich, Self-Help, supra note 7, at 350.

263. Moore formulates this requirement as follows: "[A] prompt disengagement consistent with the purpose of the action." Moore, supra note 235, at 264 
are at the same time lawful, realistic and necessary-or once there has been an effective take-over by the United Nations or another appropriate international organization.

\section{B. Procedural Criteria}

1. Exhaustion of peaceful means of settlement. ${ }^{264}$-In view of the United Nations' primary goal-conflict minimalizationand of the positive duty of its Members to seek a solution to international disputes by peaceful means, ${ }^{265}$ recourse should be had in the first instance to non-coercive methods of settlement ${ }^{268}$ - through bilateral or multilateral diplomatic contacts or resort to international organizations, including eventually non-governmental ones-unless there is clearly no time left for this type of procedures because of the imminence of the violations.

2. Absence of any reasonable prospect of timely action by an international organization.-Considering what Professor Sibert calls "the subsidiary character of humanitarian intervention,"267 priority should always be given to the international organizations, ${ }^{268}$ both universal and regional, as the best suited instruments to represent the inclusive interests of the world community. It seems indeed advisable that States should only be allowed to resort to force unilaterally for the protection of human rights,

(emphasis added). Lillich advances an equally relative and flexible criterion: withdrawal as soon as the mission is completed. Lillich, Self-Help, supra note 7, at 350. Compare, Proposed Resolution, supra note 216, at 366-67.

264. Nanda, supra note 131 , at 475 , refers to the "lack of any other recourse." Compare, Nanda, in Humanitarian INTERVENTION AND THE UNITED Nations 78 (R. Lillich ed. 1973); Perez-Vera, supra note 139, at 419; Reisman, supra note 4, at 179 . See also De Schutter, supra note 130 , at $29-30$, setting out a complete set of procedural steps to be taken by a prospective intervenor; Proposed Resolution, supra note 216, at 349-50 \& 364-65. 33.

265. U.N. ChARTER, art. 2, para. 3. See also id., art. 1, para. 1, \& art.

266. Compare, Proposed Resolution, supra note 216, at 362-64.

267. 1 M. Sibert, Traite de Droit International Public 353 (1951). Compare authority in note 234 supra and accompanying text.

268. "Wherever practicable any such intervention should be undertaken by or on behalf of the United Nations, or through the appropriate regional organization. . . J"Jenks, supra note 191, at 30 (emphasis added). See also Reisman, supra note 4, at 188; Proposed Resolution, supra note 216, at 357 . Compare, Falk, in HumanitaRian INTERvention aND tHe UNITED Nations 68-69 (R. Lillich ed. 1973); Moore, id., at 99 . This seems particularly advisable in situations where the solution of the human rights problem is likely to require fundamental alterations of the authority structures of the State intervened in. See authority in note 260 supra. But see De Schutter, supra note 130, at 31, who considers the United Nations the only agent likely to carry out a humanitarian intervention with sufficient guarantees of independence and disinterestedness. 
where the inevitable delay, still inherent in international decisionmaking as a result of the present structure and composition of the United Nations and of other international organizations, ${ }^{269}$ would prevent timely action, ${ }^{270}$ or where it has become obvious that the likelihood of such a body taking significant measures to remedy the situation ${ }^{271}$ has actually become illusory. ${ }^{272}$

3. Immediate full reporting and submission to the appropriate international organization.-In order to ensure an acceptable degree of disinterest on behalf of the intervening State, and to reduce the opportunities for abusive invocation to a minimum, it is of fundamental importance that the intervenor's motives be submitted without delay to the appraisal of the regional or world community. ${ }^{273}$ In an attempt to avoid repetition of the jurisdictional conflicts between the United Nations and regional organizations, ${ }^{274}$ such as arose for example in the context of the 1965

269. Thapa argues that:

[T] he regional organizations such as OAS, OAU .... as miniature forms of collectivity, confront lesser problems than the universal collectivity of the United Nations, and could be helpful for maintaining regional peace and order. [T]he difficulty with this arrangement is that regional organizations do not cover all geographical regions of the world, and where they exist they do not fully represent the States within the region. Interblock hostilities have penetrated into the activities of these organizations; each organization is dominated by one or other rivals. Besides, the intra-regional rivalry among the members themselves poses some practical difficulties in launching a unified action.

Thapa, supra note 188, at 71 and 73. Compare, Frey-Wouters, in HumanitaRian INTERVENTION AND tHE UNIted Nations 96 (R. Lillich ed. 1973). See also note 188 supra.

270. Reisman, supra note 4, at 178 and 193.

271. "Collectivity of regional or universal organizations has not, up till now, proven itself effective in taking over the task of humanitarian intervention." Thapa, supra note 188 , at 15 .

272. Thapa concludes that:

In absence of armed sanctions, it seems too optimistic to hope that the

United Nations will ever be able to coerce the States to follow its pronouncements on human rights. As a result of the impotence of the

United Nations, the only possible means of protecting the life of nationals as well as foreigners can be said to have been left in the hands of the States who have the might and means.

Id., at 68. Compare, Weston, in HuMANITARIAN INTERVENTION AND THE UNITED Nations 85-86 (R. Lillich ed. 1973).

273. Reisman, supra note 4, at 188 and 193. See also Nanda, in HuManitaRLan INTERVENTION AND the UNited Nations 78 (R. Lillich ed. 1973). Compare, Gottlieb, supra note 189 , at 416 , requiring authorization by "appropriate international instruments."

274. See generally Moore, The Role of Regional Arrangements in the Maintenance of World Order, in 3 THE Future of the INTERNational Legal ORDER 122 (C. Black \& R. Falk eds. 1970) [hereinafter cited as Moore, Regional Arrangements]. 
intervention in the Dominican Republic, this author is inclined to limit the obligation of reporting and submission to the Security Council to the following five cases:

a) where no regional organization covers the area of the world where the intervention occurs, or has jurisdiction over this type of operation;

b) where the situation is not of a purely local nature, for instance where the intervenor and the subject of the intervention are not both members of the same regional organization;

c) where the regional organization, although competent, refuses to take jurisdiction over the case or fails, for whatever reason, to take a stand on the matter within reasonable time;

d) where the Security Council itself, or the General Assembly, sees fit to assume jurisdiction and requests information;

e) where any of the parties directly involved voluntarily refers the case to the Security Council or General Assembly. In all other instances, reporting and submission to the competent organs of the appropriate regional organization would be sufficient. $^{275}$

This solution is supported by various provisions of the Charter, ${ }^{276}$ and would have the advantage of retaining the "primary responsibility" of the Security Council in enforcement matters and situations affecting international peace and security. At the same time this would increase the chances to avoid, whenever possible, interblock rivalries by leaving the regional organizations in charge of purely local disputes, whenever the parties involved wish so and no overriding universal community interest is at stake. ${ }^{277}$

\section{Preferential Criteria}

1. Collective Action.-Even in the absence of action by the universal or regional institutionalized community, collective

275. Compare, Reisman, supra note 4, at 191-92. Contra, Moore, requiring "immediate full reporting to the Security Council and appropriate regional organizations." Moore, supra note 235, at 264 (Emphasis added). See also Brownle, supra note 17, at 299; JENKs, supra note 191, at 30; Proposed Resolution, supra note 216 , at $349-50,352-53$ \& 364-65.

276. Compare, U.N. Charter, arts. 24, para. 1, 52, para. 4, 34 and 35 with arts. 52, paras. $1 \& 3$, and 53, para. 1. See also id., art. 103.

277. On the potential advantages of a regional approach over a universal one, see Moore, in Humanitarian INTERVENTION aNd THE UNITEd Nations 100 (R. Lillich ed. 1973). See generally Moore, Regional Arrangements, supra note 274. 
operations should be preferred over individual measures. ${ }^{278}$ While it is true that "intervention does not gain in legality . . . by being collective rather than individual," 279 there is nevertheless, a presumption ${ }^{280}$ that collective action is more likely to ensure the relative purity of intentions required from the intervenors. ${ }^{281}$

This criterion, however, is merely a statement of preference meaning that, before taking action, a prospective intervenor is expected to consult with other States and to attempt to obtain their support and cooperation for the intervention. The requirement of collectivity cannot be an absolute one, ${ }^{282}$ for lack of widespread interest on the part of other States for the ongoing or threatened human rights deprivations should not leave the victims unprotected. Provided both the causative situation and the conduct of the intervenor meet the standard set out earlier a single State ought not, in principle, to be precluded from taking the necessary steps to remedy the offending situation.

2. Invitation by or consent of the State intervened in.Technically, there is no intervention if the intervenor has been asked in by, or obtained the consent of, the de jure government of the State intervened in, provided at least the authorization or

278. Reisman, supra note 4 , at 188 . See also Weston, in Humanitarian Intervention aNd the UNITEd Nations 88 (R. Lillich ed. 1973); Proposed Resolution, supra note 216, at 371-73. It has even been argued that the big powers should be barred from participation in humanitarian intervention so as to avoid cold war involvement and reduce the likelihood of abusive utilization of the doctrine. Franck, in Humanitarian Intervention and the UNITEd Nations 33 (R. Lillich ed. 1973); Frey-Wouters, $i d$., at 52; Rogers, id., at 71-72. It is arguable, however, that such a restriction woutid elimiñate anỹ possitility of humanitarian intervention to the extent that smaller nations would lack the necessary power and resources to carry out a humanitarian operation on a large scale such as might be required where the human rights deprivations cannot be remedied without fundamental alteration of the authority structures of the state intervened in.

280. But see Thapa, supra note 188 , at 14 , who observes: "[I]f we take a group or concert of States as a proper agency, the States even in this conjunction have never been disinterested with respect to other affairs of the State intervened." Compare, on collective decision-making in the United Nations: Friedmann, in Humanitarian INTERVENTION AND the UNITED NATIONS 56 (R. Lillich ed. 1973).

281. Thapa reasons that: "[B]y entrusting the power of decision to intervene to a group of States, the requirement may reduce, though not eliminate, the risk of an intervention which would primarily serve the aims of self-interest." Thapa, supra note 188 , at 42 .

282. Reisman, supra note 4 , at $178-79$ and 188. See also Moore, in $\mathrm{Hu}$ MANITARIAN INTERVENTION AND THE UNITED NATIONS 49 (R. Lillich ed. 1973); Perez-Vera, supra note 139, at 416. 
invitation is clear and unambiguous. ${ }^{283}$ However, the importance of this criterion should not be overrated, ${ }^{284}$ for two reasons:

a) Every invitation cannot be considered valid. Even express consent by an unquestionably authoritative government cannot always be retained as an automatic, fully conclusive test, since it is always possible that it was granted only under pressure. ${ }^{285}$ Furthermore, in certain cases particularly where various factions are struggling for the power, and certainly in a clear civil strife situation with uncertain issue, the representative character of the de jure government may be questioned. ${ }^{286}$ This is even more applicable where the invitation has actually been issued by some de facto authority in rebellion against the "legal" government.

b) Absence of consent,

[w] hen a considerable number of human beings . . . are in imminent danger of destruction or mulilation due to the existence of an unlawful element in the State, and especially when the alleged act has been committed deliberately by the government of the State intervened into, ${ }^{287}$

should not be taken to preclude the possibility of lawful humanitarian intervention, provided the other requirements of legality set out above have been fulfilled. Indeed,

[i]t seems certain that whether there is an express right under the terms of [a] treaty, or express consent of the State, they are simply among the evidence in support of an act of humanitarian intervention, and are not the essential prerequisite for such an act. ${ }^{288}$

283. See, e.g., Brownlie, Gunmen, supra note 192, at 144; Lillich, Self-Help, supra note 7, at 349; Thapa, supra note 188, at 93-94. See also discussion and authorities in note 16 supra.

284. "[C]onsent of the State intervened is not the 'sine qua non' for ... legitimacy [of humanitarian intervention] ...." Thapa, supra note 188, at 94. See also Lillich, Self-Help, supra note 7, at 349; Moore, supra note 235, at 264; Moore, in Humanitarian INTERVENTION AND THE UNITED NATIONS 4950 (R. Lillich ed. 1973); Nanda, id., at 78; Perez-Vera, supra note 139, at 417; Reisman, supra note 4, at $187 \mathrm{n.88}$; Proposed Resolution, supra note 216 , at 368-69.

285. Compare, Reisman, supra note 4 , at 184.

286. See Thapa, supra note 188 , at 100 , and Reisman, supra note 4 , at 184 . Compare, Moore, supra note 235 , at 348 , who restricts the validity of an invitation by the constituted authorities to a pre-insurgency situation.

287. Thapa, supra note 188, at 94 .

288. Id., at 104. Compare, on treaty rights of intervention, Reisman, supra note 4 , at $184-85$. 


\section{CONCLUSION}

In advocating recognition of a limited right of unilateral humanitarian intervention, this author is not unaware of the serious dangers this approach entails, particularly the risk of abusive invocation. ${ }^{289}$ But, as an early proponent of humanitarian intervention pointed out almost a century ago: "It is a big mistake, in general, to stop short of recognition of an inherently just principle, [merely] because of the possibility of non-genuine invocation."290

As long as the world community appears unable or unwilling to promptly respond in a collective manner to those dramatic situations where the very nature and existence of man are threatened, individual initiatives by concerned States will have to be relied upon if a viable world is to be maintained. ${ }^{291}$ Even minimum world public order, as the primary goal of the present international legal system, encompasses more than the sole elimination of forceful interactions between States, and demands a certain amount of justice and respect for the human person, as explicitly referred to in the Preamble and in article 1(3) of the U.N. Charter. This implies, of course, a refusal to allot an absolute value to the mere avoidance of armed conflict as such, and a conviction that certain extreme situations justify and require a temporary departure from a non-violent world order to achieve a more permanent stabilization of the world structure. As the Thomases put it:

289. De Schutter, supra note 130 , at 26 . This, coupled with the fear that in some future instance a theory permitting intervention for humanitarian purposes might be invoked against them, seems to be the main reason why so many States vehemently oppose this doctrine while at the same time, rather inconsistently, advocating the legality of assistance to colonial peoples. See generally Fonteyne, supra note 146 , at $220 \&$ nn.87-88.

290. Rolin-Jacquemyns, supra note 59, at 679. Compare, Fonteyne, supra note 146, at 220; Reisman, in HUMANITARIAN INTERVENTION AND THE UNITED Nations 24 (R. Lillich ed. 1973).

291. Perez-Vera notes that:

En fait, nous sommes en train d'assister à l'effacement progressif du rôle tenu par l'intervention d'humanité au sens classique, au fur et à mesure que la société internationale se développe dans le sens de sa propre organisation. ... Mais seule la tendance est acquise; le but, c'est-à-dire la mise sur pied d'un véritable système de sécurité collective, fait encore figure d'idéal lointain; ce n'est qu'au jour de sa réalisation que l'intervention d'humanité, en tant que droit étatique, aura vecu. [E]n attendant cet ordre international nouveau, il reste indispensable de préserver-dans les limites que nous avons définies-l'intervention humanitaire. Dans l'étape de transition où nous sommes, elle apparait comme le recours ultime là où les organisations internationales se révèlent impuissantes, et où les mécanismes conventionnels de contrôle ont échoué.

Perez-Vera, supra note 139, at 423-24. 
California Western International Law Journal, Vol. 4, No. 2 [1974], Art. 2

[T] $T$ here is deemed to exist a conflict between the defense of human rights and a consideration of international peace threatened by such intervention. Historical hindsight proves that in the long run the conflict is more apparent than real, for peace is more in danger from tyrannical contempt for human rights than from attempts to assert, through intervention, the sanctity of the human personality. ${ }^{292}$ 